\title{
الاصلاح الديني عند مارتن لوثر : جدل اللاهوت والسياسة
}

The religious reform of Martin Luther : dialectic of theology and politics

\section{أ ـ م . د. قاسلم جمعة راشد - كلية 1آداب / الجامعة المستنصرية

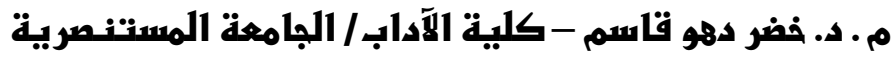

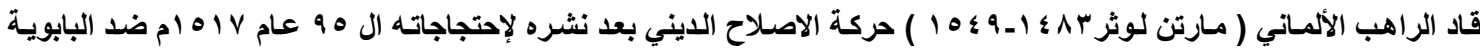
المسيحية في روما ، وفضح فيها استغلالها لمشاعر الناس الاينية بواسطة المتاجرة بصكوك الغفران ، وقد أسس إصلاحاته الاينية عبر إعادة

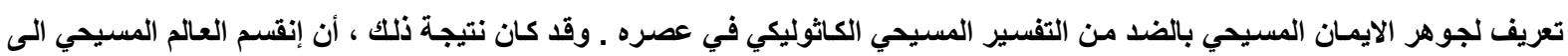
مذهبين دينيين هما : الكاثوليك والبروتستانت ـ و إطروحة هذا البحث المركزية ، هي التدليل على أن إصلاحات لوثر التي خرجت من نقاش

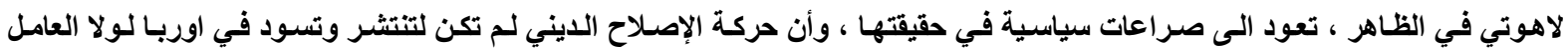
السياسي والقومي - (المي

\section{Abstract}

The German monk (Martin Luther I $\leqslant \wedge r-10 \leqslant 9$ ) led the religious reform movement after the publication of his 90 th protests in $101 \mathrm{~V}$ against the Christian papacy in Rome, exposing its exploitation of the religious feelings of people by trading the sacraments of forgiveness. He established his religious reforms by redefining the essence of the Christian faith, In his time. As a result, the Christian world was divided into two religious denominations: Catholics and Protestants. The thesis of this central research is to demonstrate that Luther's reforms, which emerged from an apparent theological debate, are due to political conflicts in fact, and that the religious reform movement would not have spread to prevail in Europe without the political and national factor.

\section{الاقدهمة}

احتفل العالم بمرور خمسة قرون على حركة الاصـلاح الديني التي دشنها مـارتن لوثر في تشـرين الأول

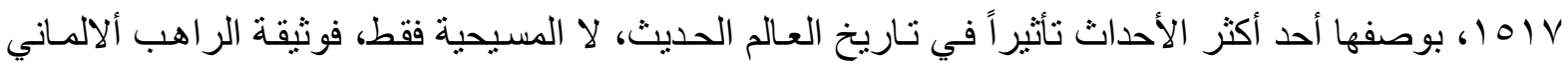
بأطروحاتهـا الخمس و التسـعين ، التـي علقهـا على أبـواب كنيسـة فيتنبـرغ الخشبية، أثـعلت فتيـل ملحمـة مـن الاضطر ابات السياسية والدينية التي غيَّرت وجه أوروبا، ونتج عنها أكبر انفصسال في المسيحية الغربية، و عدد من الحروب الدينية، لا تز ال أصداؤ ها الطائفية تتردد اليوم. مع ذلك ، كانت أحد أبرز نتائج تلك الحركة الكبرى غير المباشرة، هي إسهامها في نشأة الدولة القومية. ولعل هذا هو دهاء التاريخ ، الذي يسير إلى مقصده الأسـى عبر كوى صغيرة ونو افذ ضيقة يتم فتحها في لحظة مناسبة . حيث أفضت جهود لوثر في نهايـة المطاف ، إلى تفكيك السلطة البابوية، وبذر حبوب الدولة الحديثة ، وذلك بتمزيقها الوحدة الشكلية التي أبقت عليها المسيحية الكاثوليكية نحو ألف عام، بين القرنين الخامس والخـامس عثر المبلاديين، و عاثـت خلالهـا أوروبـا مـا اصطلح على تسميته بالعصور الوسطى المظلمة ، كحضارة مسيحية تحت إمـرة الإمبر اطوريـة الرومانية، على أرضية بنية إقطاعية.

كما يزعم البعض ان ترجمة لوثر للكتاب المقدس الى اللغة الالمانية - بعد أن كان حكراً على طبقة رجـال الدين الذين يتقنون وحدهم اللغة اللاتينية - جعلته في متتـاول أفقر الناس ، فغدا هؤلاء لا يحتاجون الى إرشـاد 
كنسي ـ وقد أوصل ذلك الثعب الألماني الى أعظم انواع الحريـة ، كمـا يقول الثـاعر الألماني هـانريش هاينه ،

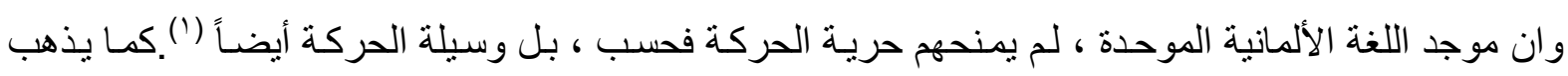

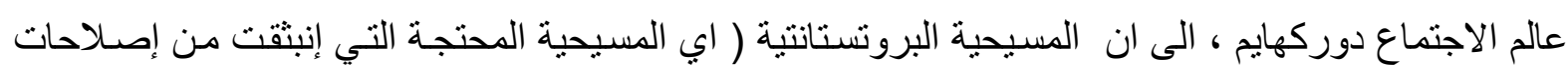

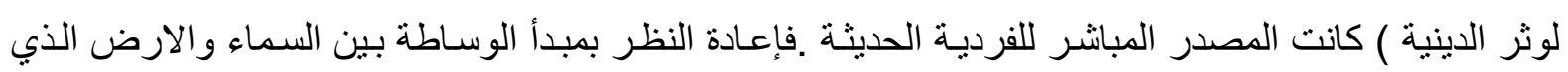
جسدته الكنيسة ، تشكل الخطوة الاولى باتجاه العصر الحديث ( أبي الحداثة)، حيث تؤدي العزلـة التي قاد اليها

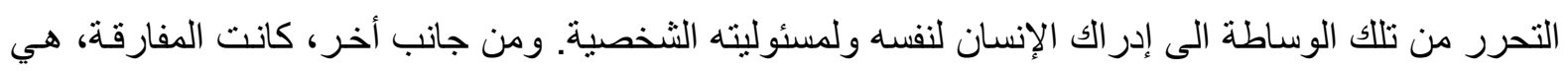
أن الوجه الآخر لمذهب لوثر هذا ، هو تشدده بإقرار عبودية الأرادة الإنسانية في مقابل الأر ادة الألهية والقول

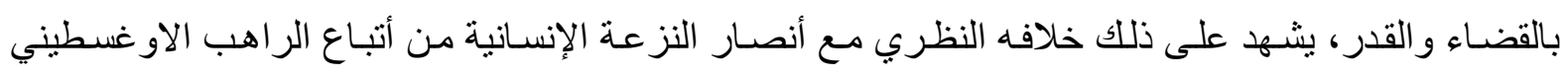

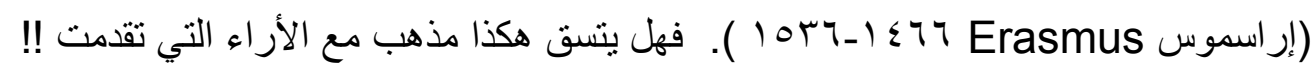

عموماً، فأن المسألة التي ننوي إثارتها في هذا البحث ، لا تقتصر ، على عرض مضـامين إحتجـاج لوثر وطبيعة برنامجه الإصلاحي ـ فصحيح أن السلطة البابوية المسيحية التي جعلت من نفسها محتكرة الحق في فهم الدين و لاهوت السماء ، ووريثة ذخائر الانبياء و القديسين و المتاجرة بها ـ كانت سبباً ور اء ذلك ـ ـوصحيح أيضـاً

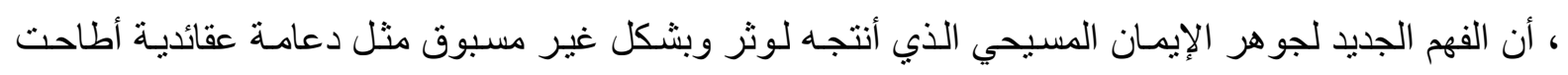

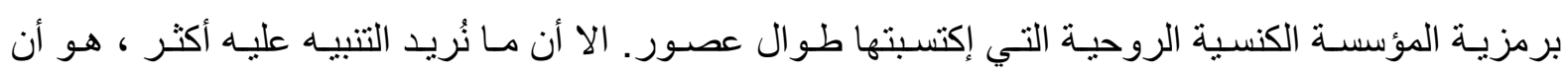

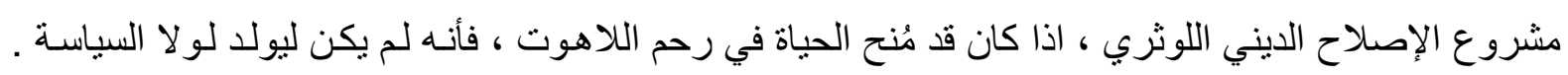

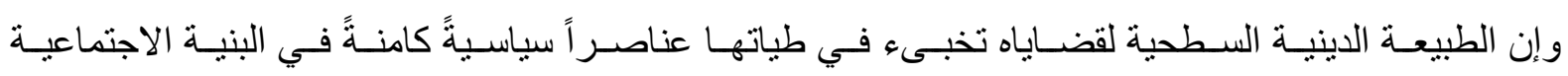
و الاقتصادية للو اقع الألماني و الأوربي لذلك العصر، فإطروحات لوثر اللاهوتية تحمل نقيضـها الجدلي في واقع سياسي واجتماعي مأزوم. هذا هو ما ننوي الكثف عنه مفصلاً في ثنايا البحث.

\section{المبحث الآول : شخمية لوثر وقاقه الروحي}

اولاً : طفولة قاسية ولد مارتن يوحنا لوثر في بلدة ايسليين ( التابعة الى مدينة إيرفورت حالياً ) في ـ النوفمبر

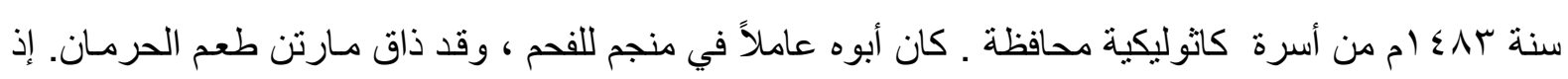
يقول : كان و الداي فقيرين جدًا فكانت و الدتي تحمل الأخشاب على ظهر ها لإعالتنا، لقد كانت حياتهما قاسية جدًا ـ وكانت معاملة الأسرة للأبناء تتسم بالقسوة حتى أن أم مارنن ضربته بالسياط بسبب حَبة جوز حتى انفجر الدم

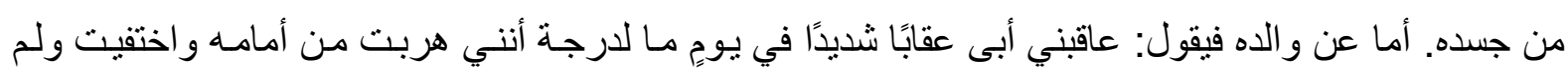

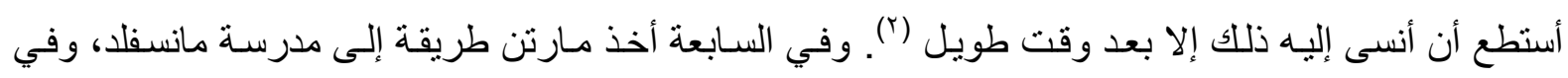

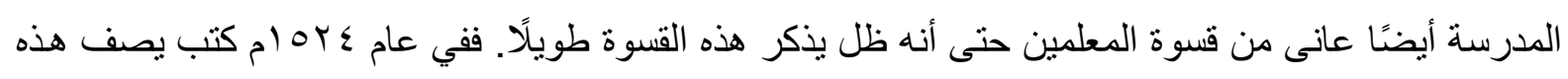

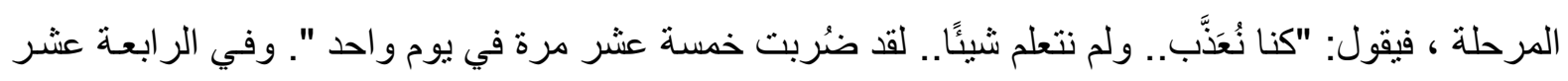

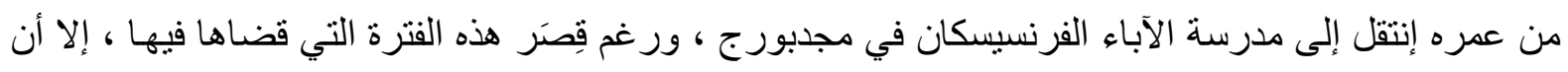
مارتن تأثر جدًا بجماعـة الفرنسيسكان التي تقوم بممارسـات شديدة في الزهد و التقشف و الإماتات و الاتضـاع. كانت هذه الجماعة تعيش على الصدقة ، فكان مـارتن يجوب الثوار ع مع أصدقائه طالبَا الصدقة من الناس. 
وتكرر الأمر في مدرسة القديس جورج في مدينـة أيزنـاخ ، حيّن انضم مـارنن إلى مجموعة من الثباب الذين

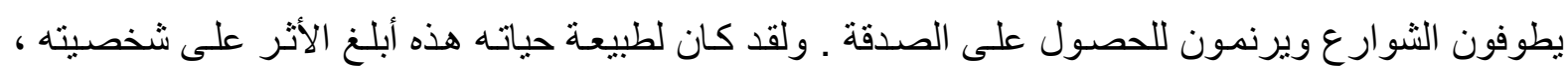
فنجده يقول: "لا تستهينو ا بالصغار المتسولين لأني كنت مثلهم ، نعم كنت فتى مسكينًا مستجديًا وارتقيت إلى مـا أنا عليه بقلمي "(r). (") على أية حال ، كانت طفولة لوثر وتعليمه المبكر نسودهما التربية القاسية والمذلة ـ ورغم كون هذا الأمر

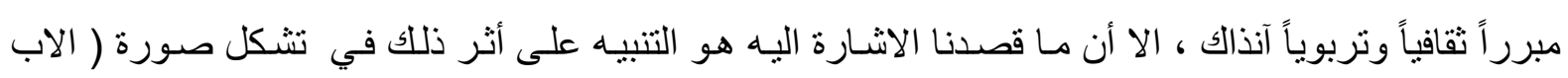
السماوي ) المر عبة في نفس لوثر منذ طفولته ، و هي صورة تجتاف نفسياً صسورة الاب الارضي ، وهو الأمر التر الذي اقض مضجعه لاحقاً. ثانيا ـ الراهب الثاب الممزق: في سنة الـ إم، دخل لوثر إلى جامعة إرفورت حيث درس الفلسفة والعلوم الأخرى الى جانب در استه للكتاب المقد، و عكف على القراعة حتى أن أصدقاؤه لقبوه بمـارتن الفيلسوف، وقد

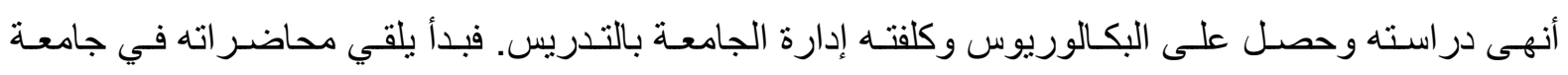

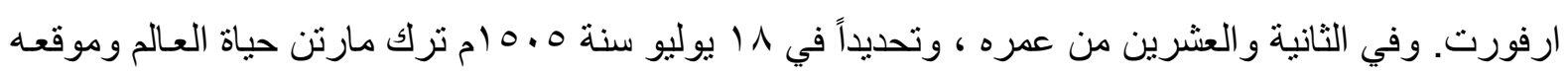

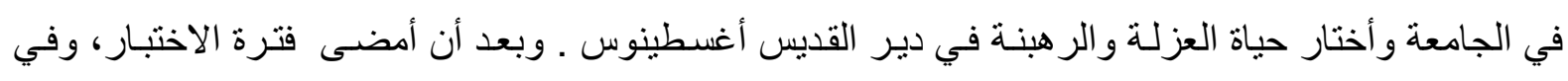

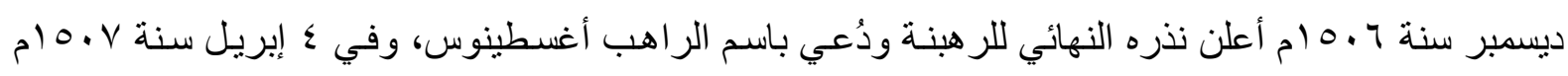

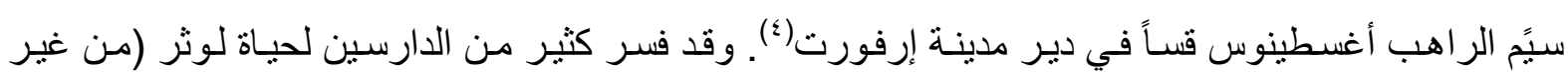
المستبعد أن مصدر ذلك هو العداء المذهبي) تحوله لار اسة اللاهوت وتفضيله لحياة الرهبنة على الحياة الجامعية ، بشكل مبالغ فيه ، حين عللوه بصورة مباثرة الى حادثة وقعت للوثر قبل إتخاذه لقر اره هذا ـ تلك الحادثة

تمثلت كما يروون ، هي وقوع صلاعقة بالقرب منه ، نذر على أثر نجاته منها نفسه للر هبنة بقية حياته(')! دخل لوثر الى الدير ، وكانت قسوة الحياة فيه هي المنهج المتبع ، اذ كان الرهبان يصلون سبع مرات في

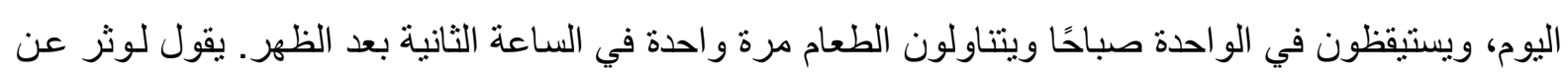

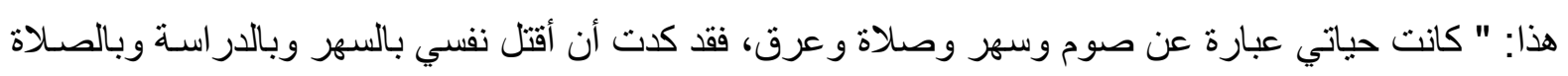
وبالأعمال الكثيرة الأخرى". وفي موضع أخر يقول : "عندما قمت بخدمة أول قداس لي شعرت أني على حافة الموت "(؟). و علق على هذا القس البروتستنتي حنا جرجس الخضري قائًا: " لقد اعتقد البعض أن الخطية هي السبب الأول و الدائم الذي كان يثير الخوف و الرعب و الاضطر اب في نفسية لوثر، وممـا لاشك فيـه أن الخطية كانت سبيًا من أسباب اضطر اب لوثر، على أنها لم تكن السبب الأول والأساسي... لأن السبب الأول والأساسي

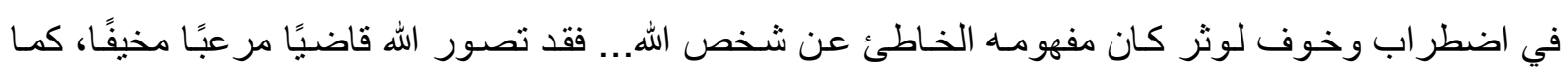
تصور يسوع المسيح ديانًا مهيبًا ولم يحاول أن يرى يسوع المسيح مصلوبًا على الصليب بدافع الحب... لكنه كان

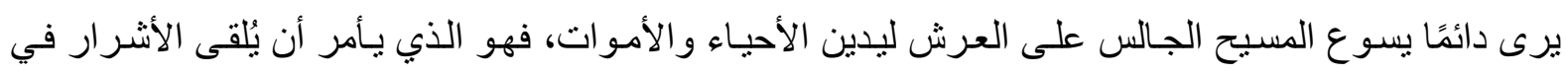

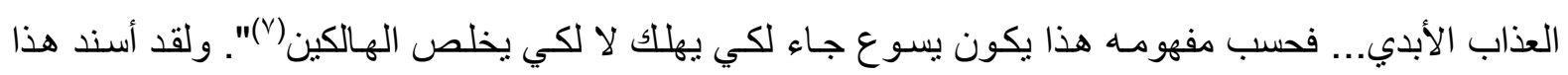
الباحث رأيسه بنصسوص للوثر يصف فيها حالته النفسية قائلًا: "لقد رأى الآخرون في حياتي مظهرًا عظيمًا 
للقداسة على أنها لم تكن واضحة في عيني فقد كنت محطمًا وحزينًا ... لا بـأس بحالتي الجسمية ولكن نفسي تتعذب... إن نوبات اليأس تجتاحني، وعو اصف القنوط قد انهالت علىّ"(^). وفقاً لللك، فسر خصوم لوثر العقائديون حالته هذه، على أنها إضطر اب روحي شيطاني ـ فكم من الليالي قضى و هو راكع على البلاط يصلي للقديسين لكنـه مـا أفاد شيئًا رغم أنه أصـاب جسمه الهز ال و عقله الشطط فكان يرى أرواحًا وشياطين تحيط بـه. لقد كان يسعى للحصول على سـلام الله بمجهوداتهـ وبره ومـع ذلك لم لم يحصد إلا الفثل ـ مما دعا المحلل النفسي اريك اريكسون في كتابـه ( الثـاب لوثر)، للاعتقاد بـأن لوثر مصـاب

بمرض عقلي، محتجاً بحالات القلق و الخوف التي كانت مر افقة للر اهب الاو غسطينيَ'(9). و إننا نرى أن تقييم حالة لوثز هذه يجب أن يتصف بروح الموضو عية ، لا إطلاق الاتهامات والاحكام دون

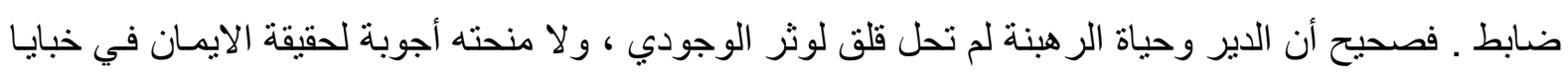
روحه ، ومع أنه لم يجد ليأسه من نفسه حين هجر الدنيا ودخل الدير من عزاء ـ الا أن ذلك لا يعني أبتسـار كل

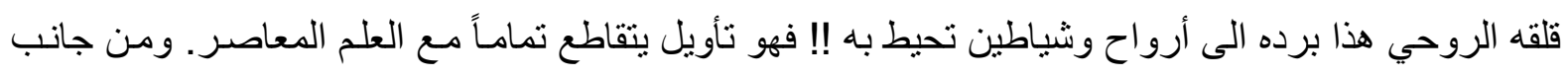

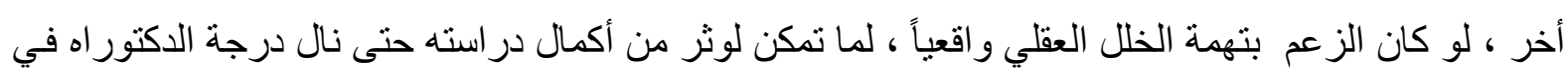

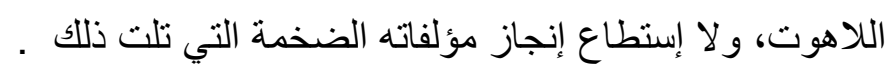

وسيرة لوثر العلمية تشـهـ على براعة عقله ، لا مرضـه ـ فالى جانب دراسته اللاهوت و الفلسفة ، فقد

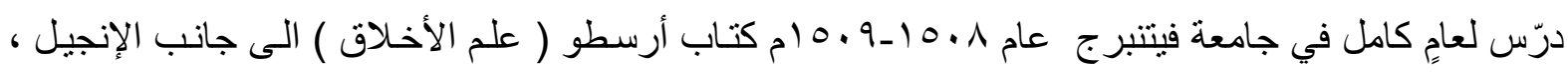

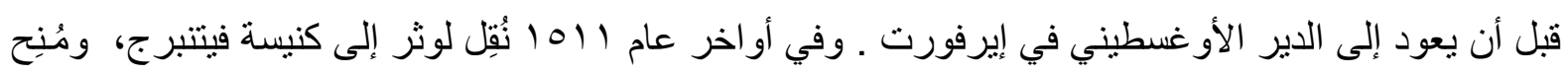

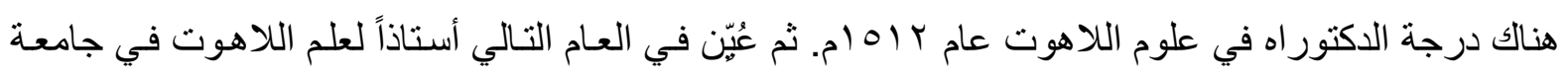

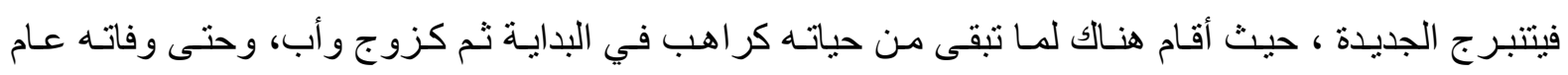
$(1 \cdot)^{\circ} 10 \leq 7$

إن هؤلاء لم يتسـوا في رؤيتهم للوثر الراهب القلق ـ إنـه أقرب الى كيركجورد في ازمتـه الوجوديـة

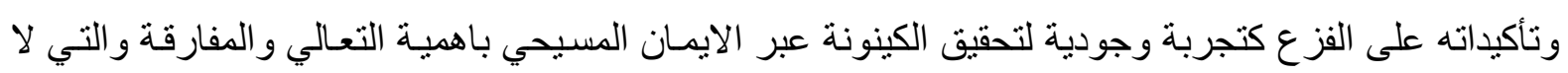
تتتهي الا بفعل الايمان في المرحلة الدينية ('"). وإن مصدر القلق الروحي الذي عاثـهـ لوثر يعود الى طبيعة

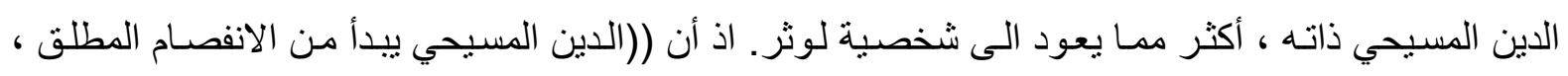
ويبدأ من الألم، وذلك من خـلال كونـه يمزف وحدة الروح الطبيعيـة فيدخل الاضطر اب على السـلام الطبيعي . فالإنسان يبدو في الدين المسيحي شريراً ( بالفطرة ) من الأصل و هو في منظوره كائن سلبي إزاء ذاته في

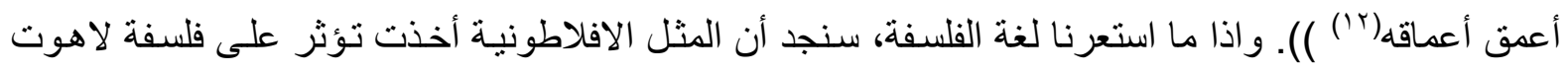
الخلاص عند لوثر، إذ إن ((المسيح والروح القدس يحييـان اعمـال الايمـان و البر، مثلمـا الفكرة الافلاطونيـة ،

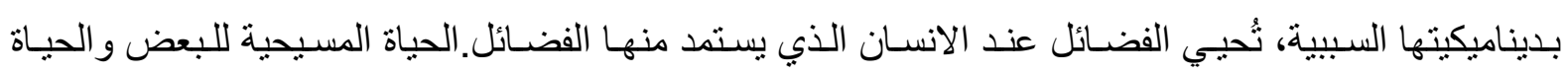
الفلسفية للبعض الاخر ممكن تفسير هما تماماً بديناميكية السبب الصاعد ، الى درجـة ان تدّّل الاسباب المتماثلة الكامنة في الانسان نفسه ، يصبح بدون فائدة ... فالالحاح على وجود مباثـر وشخصي للقوى الصـاعدة الالهية 
في حياة المؤمن ، التي تعبر عنه هذه الافلاطونية ، كان من شأنه من ان يضاعف متطلبات الكمال الروحي التي

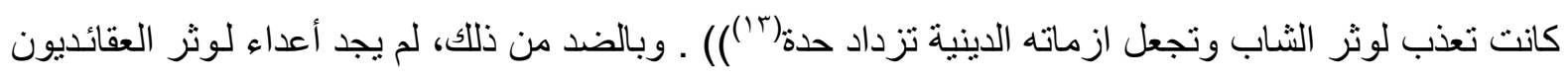
من وصف لضميره الروحي المعذب ، غير إتهامه بالهلوسات و القلق المرضي واستيلاء لشيطان عليه ، وكأن الثيطان لابد ان يُلازم كل مفكر يرمي الى اصلاح مـا فسد ، بدئًاً من جنّي سقر اطو ومروراً بشيطان ديكارت

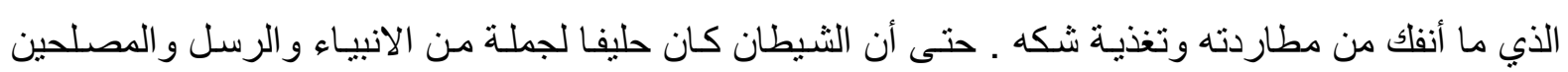

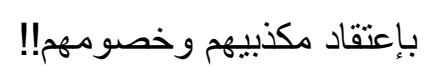

\section{المبمث الثاني - لاهوت الخلاص}

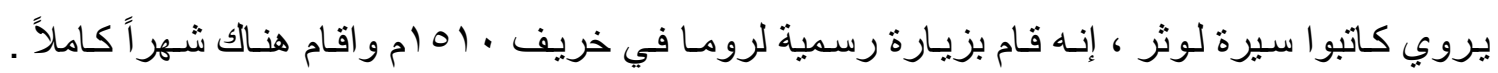

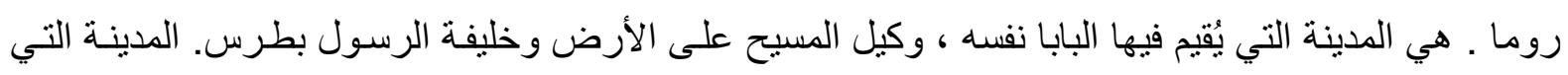

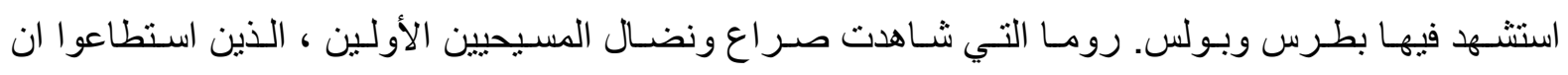

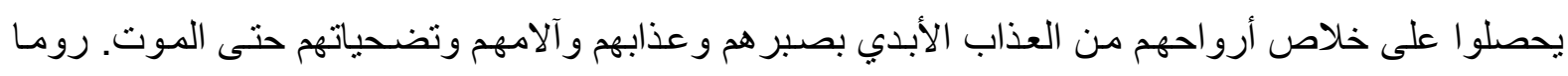
التي امتلأت بالكنائس وبذخائر القديسين وعن طريق زيارة بعض هذه الكنائس وبعض ذخائر القديسين بسنطيع الإنسان التائب ان يحصل على غفر انات كثيرة ولسنين عديدة( ').

إن زيارته هذه ، كانت قد شكلت صدمة عاطفية له ، وهي قد فتحت عيني لوثر فيما بعد، وبعد عدة

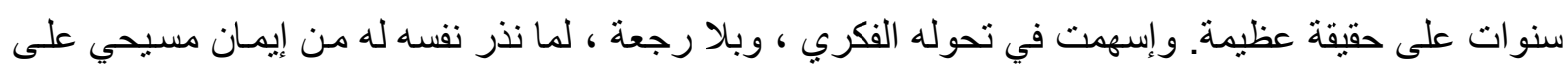
الطريقة الكاثوليكية. فبعد أن كان قد عزم ان يعترف اعتر افا شاملا كاملا لكي يحصل على اكبر عدد من النعم التي و عد بها الله عن طريق ذخائر القديسين الموجودة في المدينة. الا أن ما كان ينتظره هو حالة الرهبان الذين نزل عليهم ضيفا وحالة الكنائس والاكليريوس عامة. كان بعضهم يعيش عيشـة البذخ و الرفاهية، كأمر اء وحكام

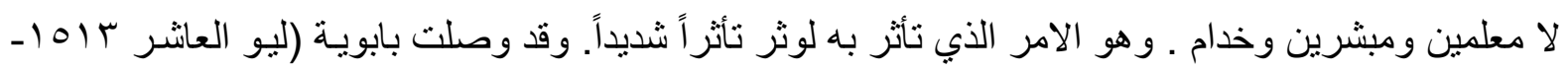

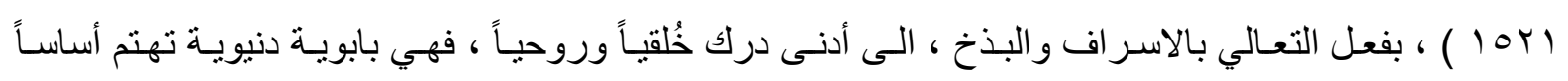

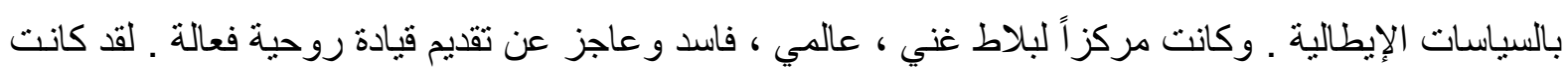

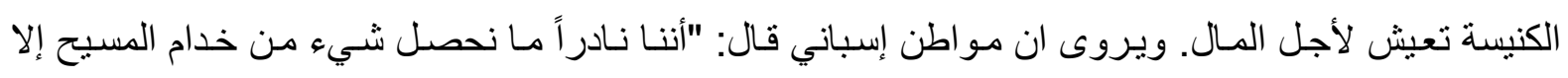
بالمال ، في العماد بالمال ، في الزواج بالمال، الاعتر اف بالمال، لا يدقون الاجر اس بدون المـال ، لا مر اسم في لاسي

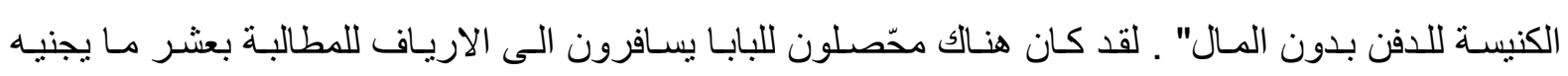
الفلاحون ، وكانت للكنيسة ضر ائب تفرض سنوياً على الدول(10).

ويرى عدد غير قليل من الباحثين في سيرة لوثر ، انـه أكتشف الفكرة المركزيـة التي دفعت نحو إنقلابته

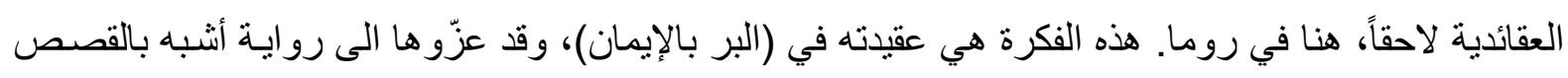

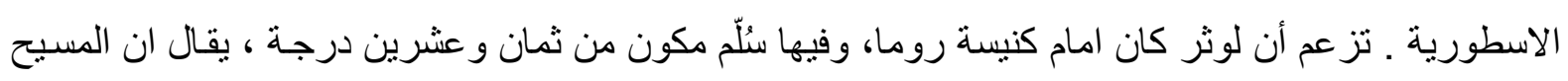

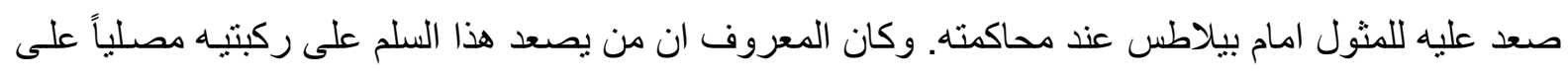

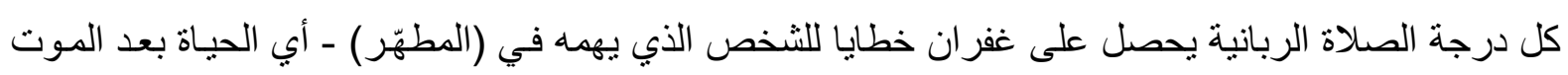


وقبل القيامة - ـ وقد أرد لوثر أن يخَلِص روح جدّه من المطهر وصعد سلم بيلاطس، وكان ينلو على كل درجة

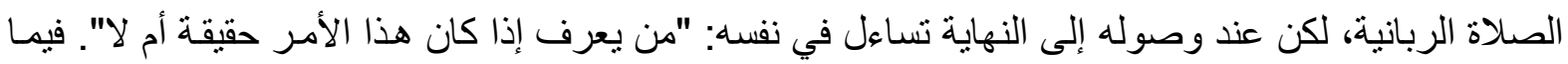

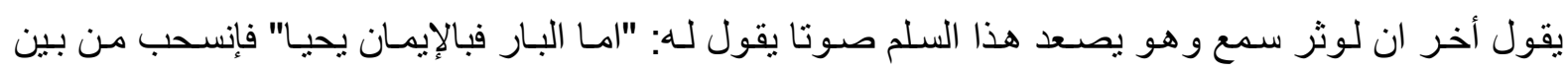

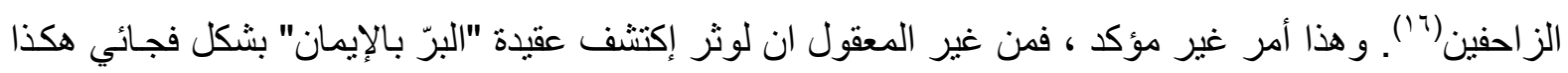

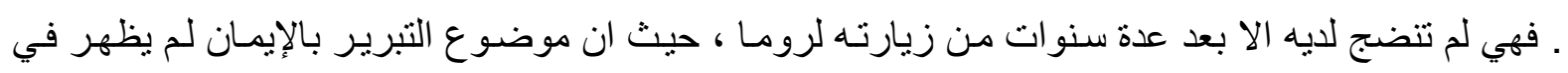

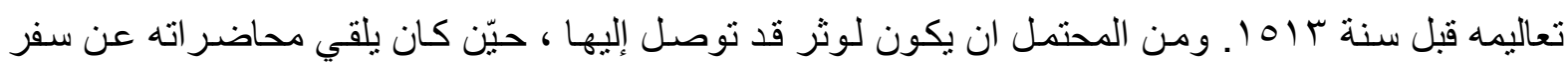

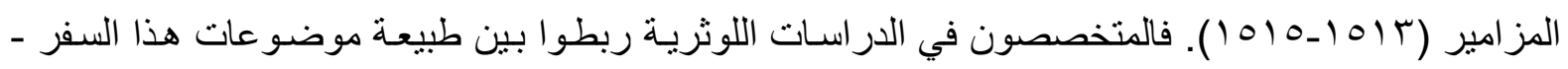

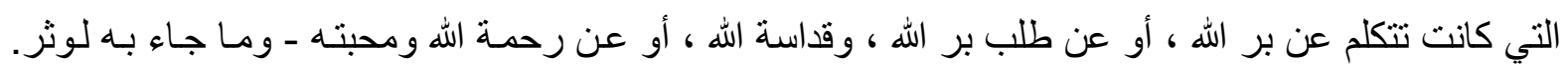

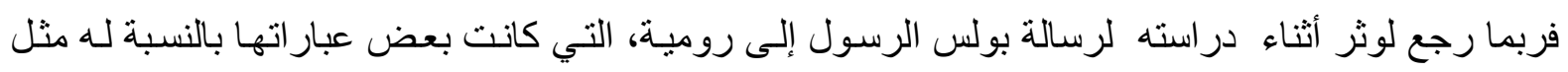

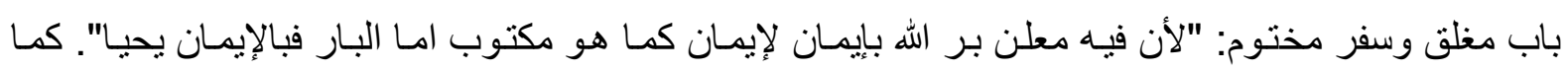

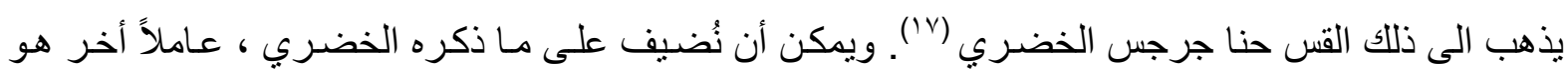

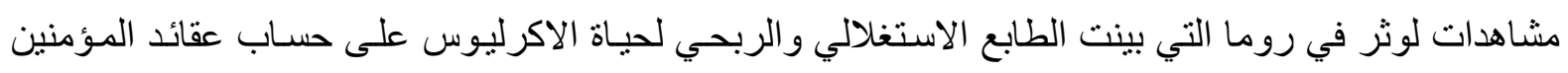

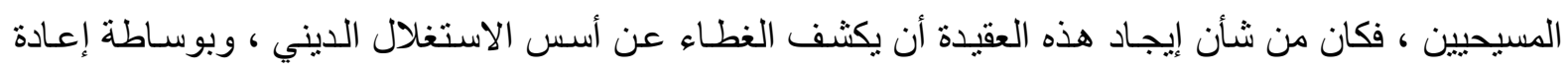

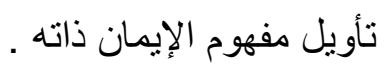
إن أساتذة لوثر الكاثوليك علموا بان " بر اله " هو عطية من الله ، ولكن هذه العطية تمنح للذين يتعاونون

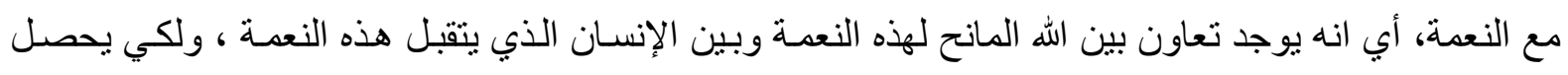

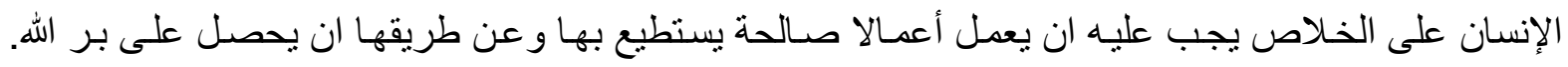

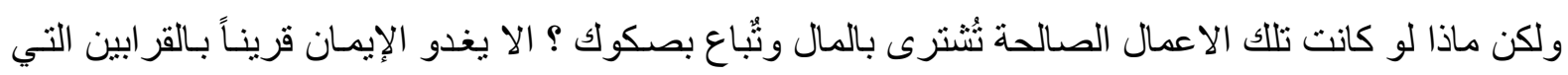

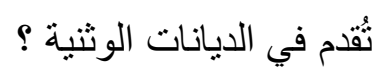

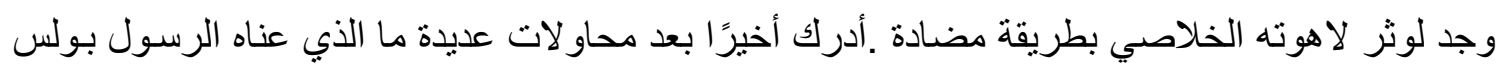

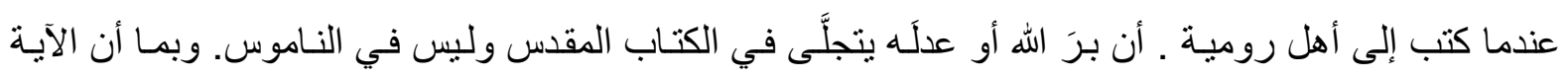

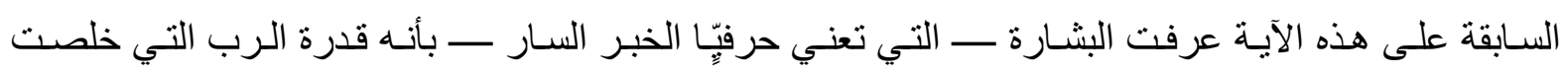

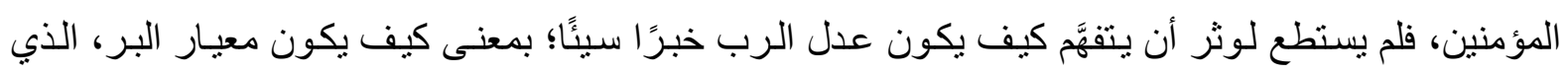

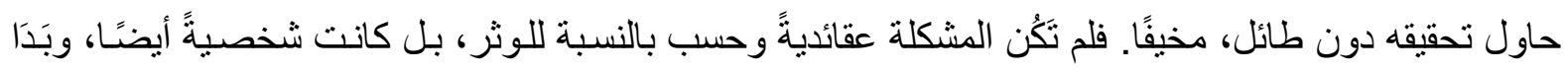

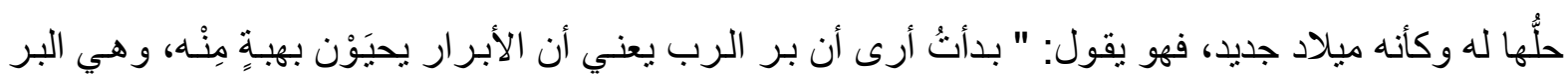

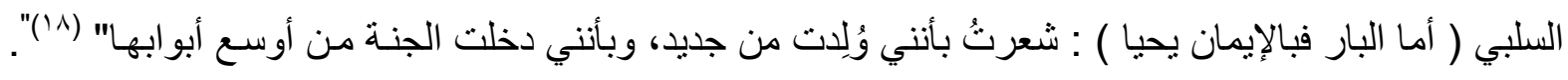

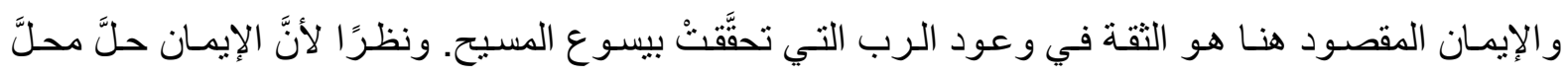

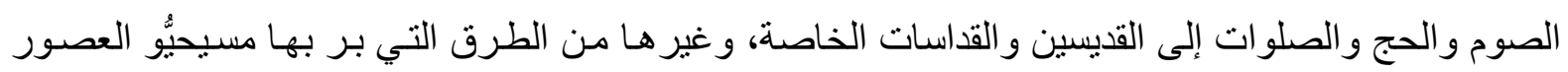

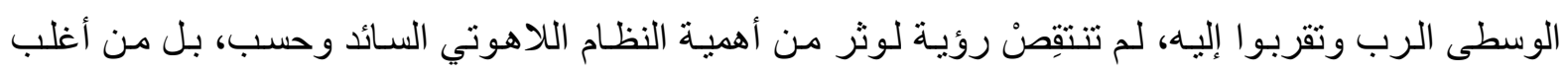

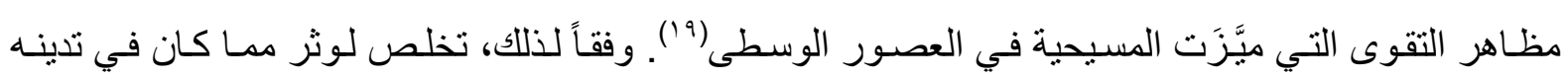


الثخصي من تصارع بين ايمان باله غاضب لا يرحم و اله رحيم طيب. وهذا الموقف لا يمكن أن يكون مر افعـة

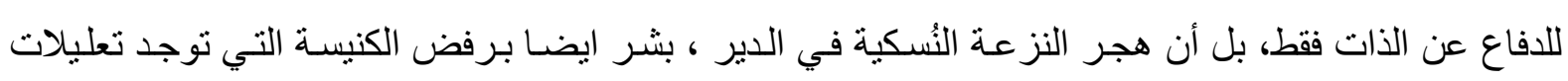
لعذاب للضمائر المصاحب لتلك النزعة ع.r) .

لقد مثلت عقيدة لوثر الجديدة (البر بالإيمان) إحتجاجاً، بل إنقلاباً على كل التقاليد الكنسية التي إمتدت لعصور طويلة ، وضربت في الصميم الوساطة الروحية لرجال الدين، تلك الوساطة التي تصر على إنها معر اج لاجي بين الإنسان و الله ، واستعاض هو عنها بضمير الإنسان الفرد. لقد استعاض بالحياة العاطفية للايمان. عن جميع

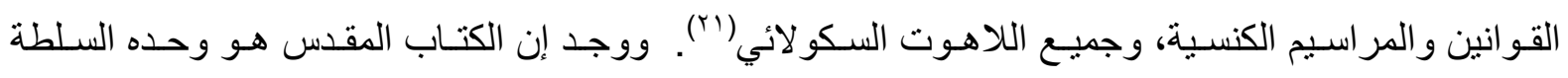

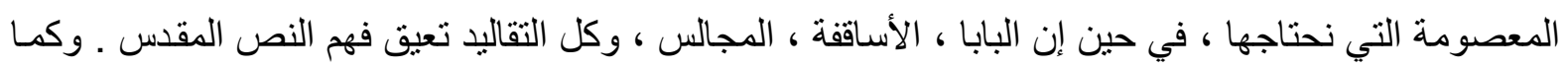
يرى لوثر في عقيدته ، كهنوت كل المؤمنين universal priesthood ، و التفسير الحرّ للنصوص المقدسة،

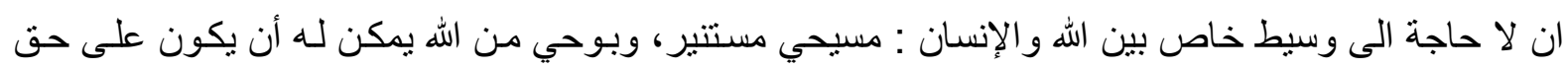
في مواجهة الاكرليوس ، وبالتالي يمكن لكل إنسان أن يبشر بكلمة الله (rr). و هكذا، توصل لوثر الى أن الاعمال الخيرة ليست هي مـا تصنع الانسان الخير يبل ان الانسـان الخير هو الذي يصنع الاعمال الخيرة ، فهو يردد انني اخشى اعمالي الخيرة اكثر مما اخشى اعمـالي الثريرة، لمـاذا؟ لان الاعمـال الخيرة يمكن ان تعرضنا لخطر الابقاء في انفسنا على نوع من الاطمئنان الكاذب، وعلى نوع من لن السلام الخادع، في حين ان الخلاص لايمكن ان ينال الا عن طريق كفاح يدوم في كل لحظة .ان الاغر اء ،لاء بـل

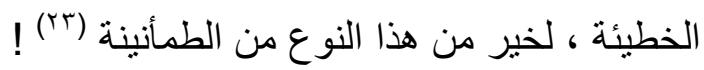

ان الخلاص متعلق بجو هر الانسان ورؤيـة الله لنفس المؤمن من البـاطن لا الظـاهر ، فالطقوس والاعمـال

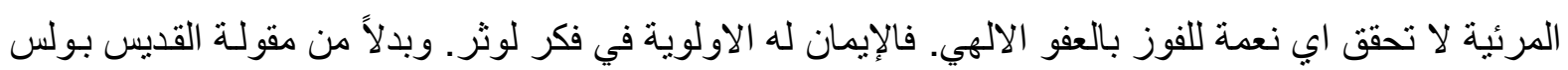

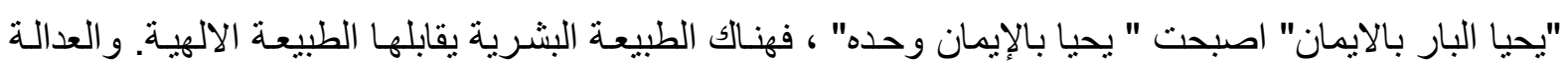

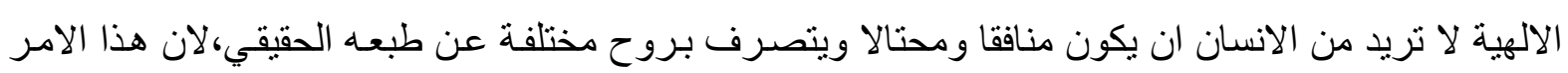

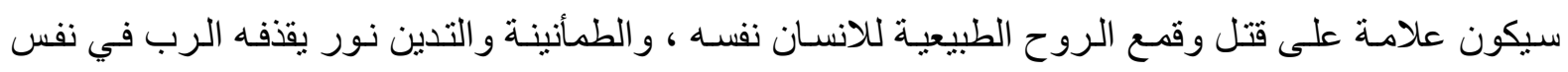
الانسان المجبولة بطبعه (ז)

نتيجـة لذللك، كل الأعمـال التي يقوم بها الإنسـان - ليسـت فقط الأعمـال الخارجيـة ، المتعلقـة بـالطقوس و الأعمال الدينية، بل أيضاً الإعمال الاخلاقيةـ التي يجدها جديرة بـأن يتصـالح بفضـلها مـع الله وان ينـال النعمـة و النعيم الإلهيين ، هي عبـث وباطل ((المسبحة، الطعام الملائم للصوم، الحـ، القدّاس، بيع صكوك الغفران، ثو اب الر اهب ، حجاب الراهبة ... اذا تمكّنا من الفداء من الأثم بالأعمال ومن ثم ننـال النعمـة ، فـأن دم المسيح

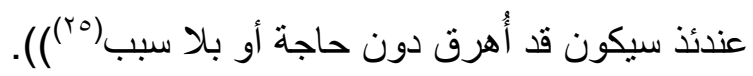

ويورد لنا الفيلسوف فيورباخ ( في كتابه " جوهر الإيمان بحسب مارتن لوثر" ) ، نصوصـاً للوثر تفسر ذلك: ((يقولون إنهم يريدون أن يكفروا عن خطيئتهم ويصبحوا مباركين من خـلال حياة صسارمة ، إنهم يضفون 
على الأعمال والزعماء الروحيين مما يليق بالمسيح والإيمان ـ ما الذي يكونه هذا غير إنكار للمسيح ... إلى أين

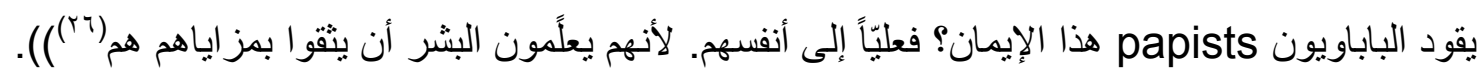
ان المسيحية بحسب لوثر، لا تتحصر غايتها على الاطلاق في ايجاد تطابق بين الارادة الانسانية والنعهة

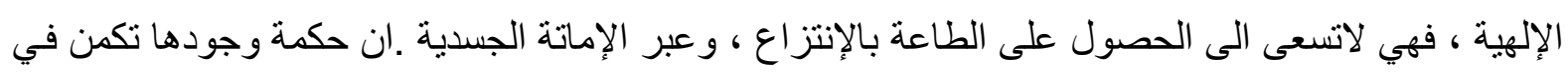

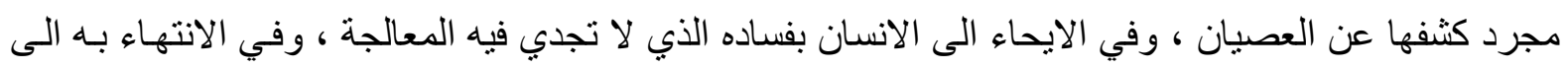

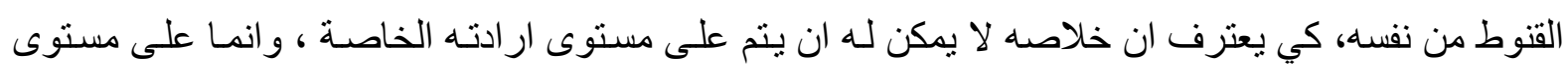

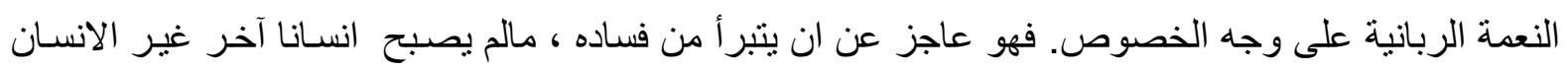

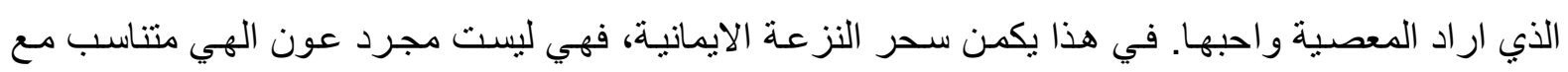

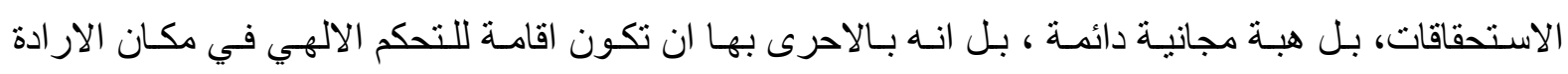

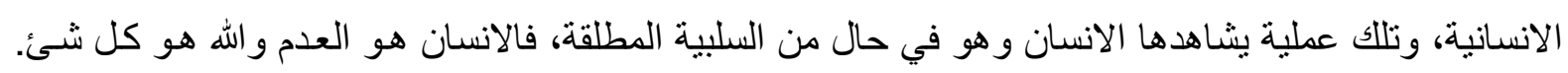

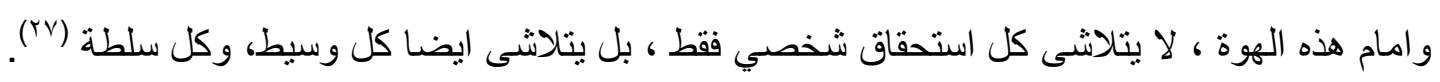

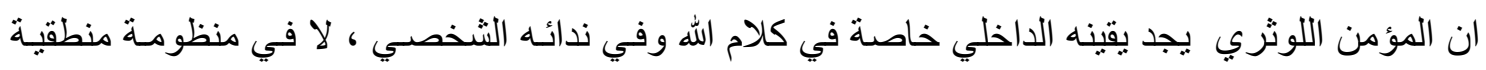

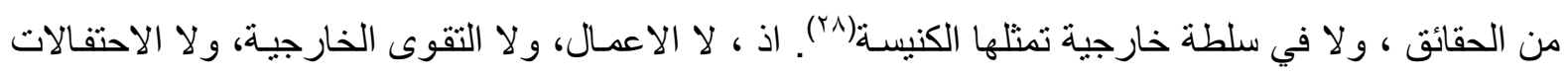

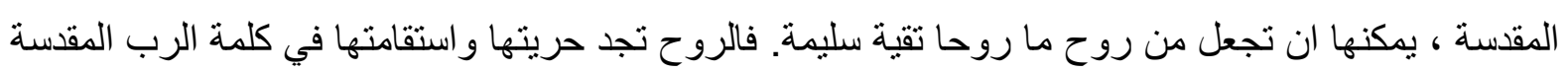

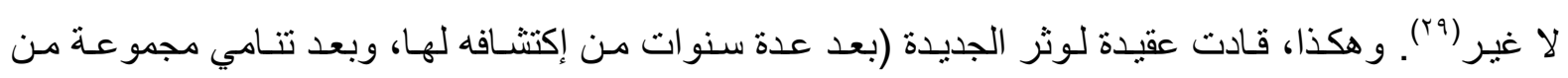

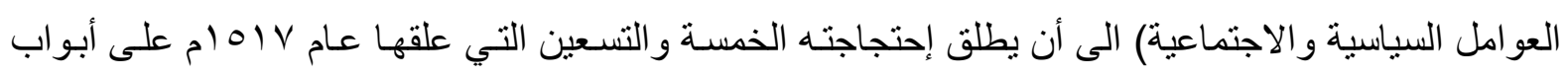

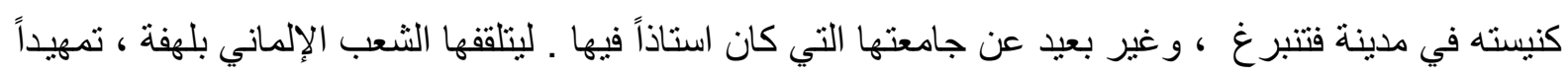

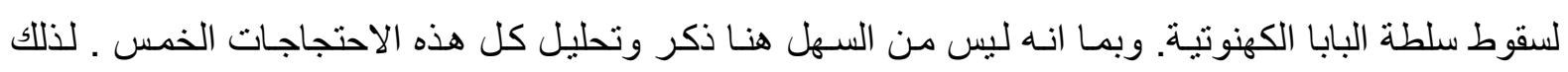

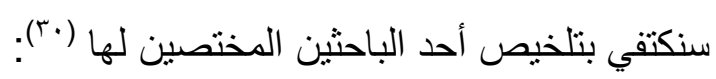

الإحتجـاج الأول: (عندما قـال ربنـا وسيدنا بسوع المسيح "توبوا" أراد بذللك ان تكون حياة المؤمن كلها توبـة

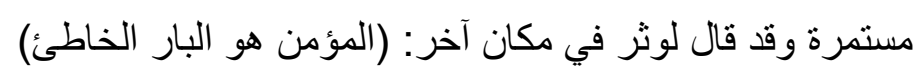
الإحتجاج الخامس: (لا يستطيع البابا- حتى لو أراد- ان ينقذ الإنسان من عقوبـة قانون ، الا مـا سنه هو نفسـ بمحض إرادنه ).

الإحتجاج الساد: ( ليس في سلطان البابا ان يزيح أو يلاشي عن الإنسان عقاب خطيئته أو يغفر له، و إنما يعلن للخاطئ ان خطاياه قد غفرت). الإحتجاج الحادي و العشرون: ( ضل الذين يقولون بأنه متى رنت النقود في صندوق الجمع تخلص النفس من المطهر منطلقة إلى السماء).

الإحتجاج الثاني و الثلاثون: (ضل الذين ينو همون بأنهم في أمان بسبب الغفران، فانهم مع تعاليمهم هالكون). 
الإحتجاج السادس والثلاثون: (ان المسيحي الحقيقي، الذي يترك خطايساه بقلب منسحق نـادم، تغفر خطايساه ولا حاجة له إلى صكوك غفران). الإحتجاج الثالث والأربعون: (على المسيحي ان يفهم حقيقة ان الذي يحسن إلى مسكين أو يقرض محتاجـا يقوم بعمل أفضل من شر اء صكوك الغفران).

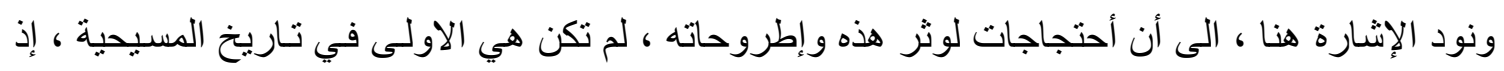

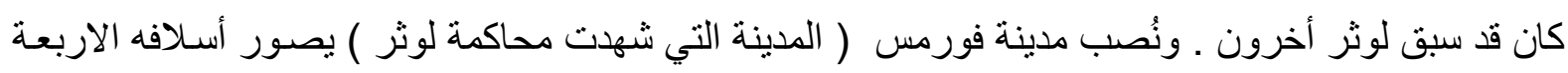

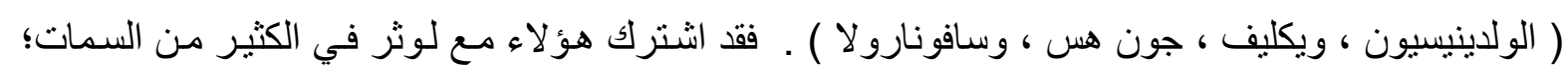

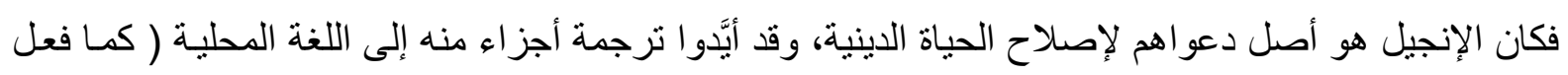

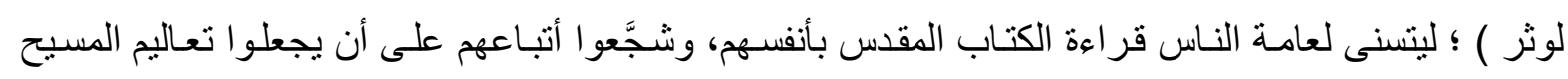
و المسيحيين الأو ائل في العهد الجديد مَتَكَهم الأعلى، وكان الوعظ الديني أداة قوية لنشر أفكار هم، وواصلوه حتى لونى

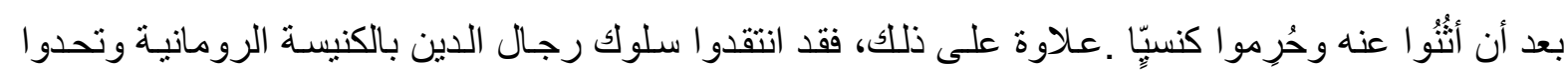

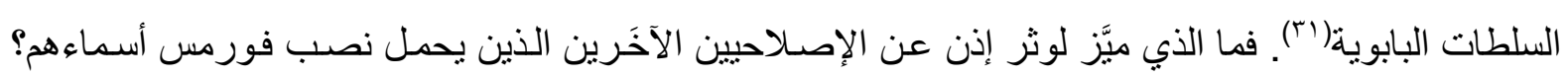

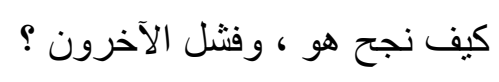

\section{المبمث الثالث- جدل اللاهوت والسياسة}

يعتقد البعض ان المصلح الألمـاني قد قام بثورة عنيفة وحرب شـعواء ضـــ الكنيسـة الكاثوليكية بعد ان

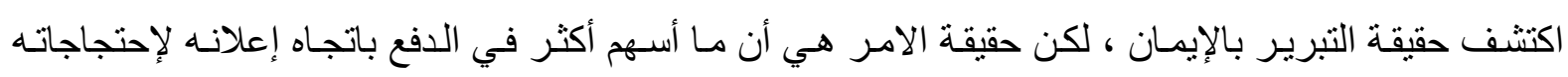

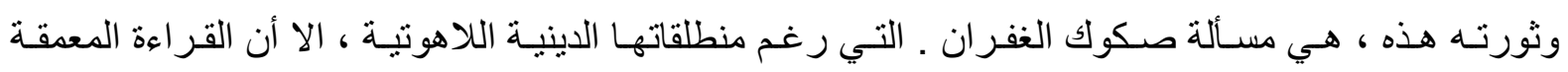
لتجلياتها تكثف عن الكثير من الدهاء السياسي الذي أخفى تحت جلبابها حربـاً إقتصسادية بـاردة ودو افع سياسية كامنة . كيف ؟ ليكن مدخلنا للاجابة عن هذا السؤال ، معرفة ما هي صكوك الغفران ؟ () (ان فكرة صكوك الغفران لم تكن جديدة في ذلك الوقت، بل يرجع تاريخها إلى زمن الحروب الصليبية،

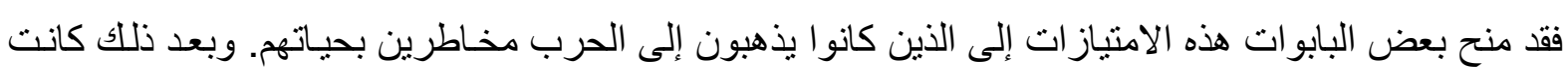

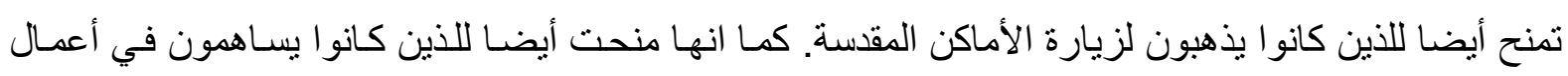

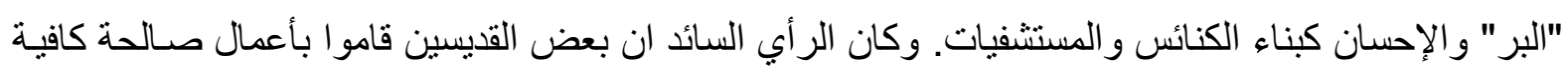
لخلاصهم فقط ، بينمـا قام البعض الاخر باعمال حسنة كثيرة زادت عن حاجتهم: مثنل السيد المسيح... كذلك قامت السيدة العذر اء مـريم و الرسل و عدد كبير من الأنبياء والقديسين في تناريخ الكنيسـة على مـر العصور

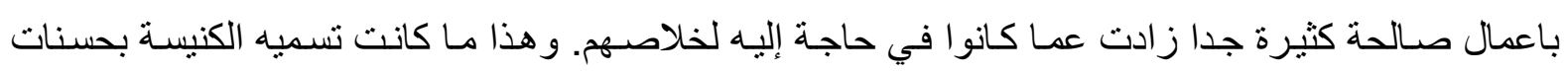
القديسين الزائدة. و هذه الحسنات الزائدة مودعة في بنك الكنيسة وهي ملك لها وللكنيسـة الحق في التصرف فيها فيها

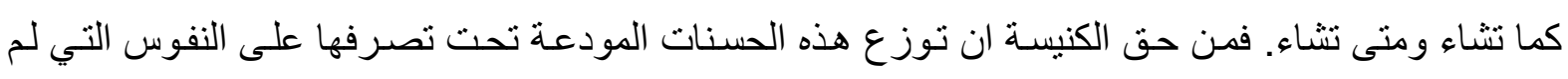

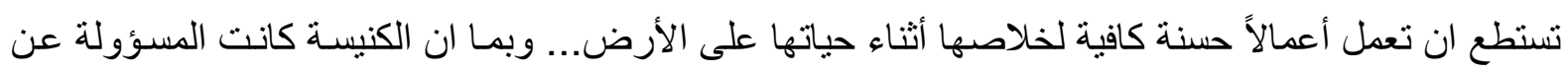
الأعمال الحسنة الزائدة. و التي تدعى كنز الكنيسة. لذلك كان يمكنها ان تبيع أيضا بعضاً من هذه الأعمال الحسنة 
لمن هم في حاجة إليها ولم يستطيعوا في حياتهم التكفير عن ذنوبهم وخطاياهم ... حتى أصبحت صكوك الغفران تجارة رابحة شائعة لجأت إليها الكنيسة في ظروف كثيرة كلما احتاجت إلى المال، بل تطورت الفكرة حتى ان

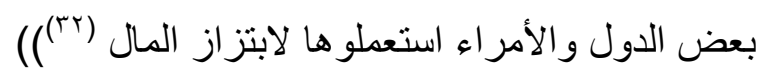

لذلك لجأ البابا ليون العاثـر( المتمسك بحياة البذخ و الثـغوف بـالفن و العمارة وبنـاء الكنائس ) الى رئيس أساقفة إمارة ماينز (Mayence) الألمانية ومنتخب مقاطعتها ، لإستغلال هذه الوسيلة لجمع المال الذي كانا في حاجة إليه. بعد أن أصدر قراراً في سنة 71017 م ببيع صكوك غفران كاملة. يمنح بموجبه الاخير نصف الاموال ويذهب النصف الأخر للبابا في إيطاليا ـ وقد كان الناس من مقاطعة ساكسونيا يضطرون للسفر الى ماينز لشراء

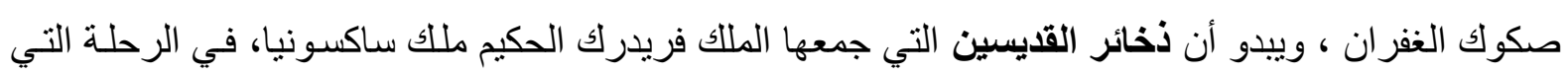

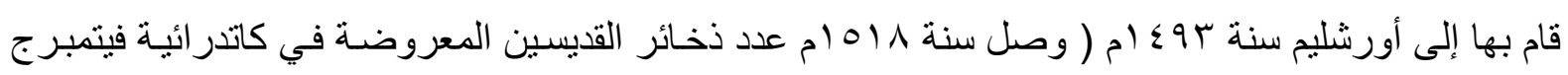

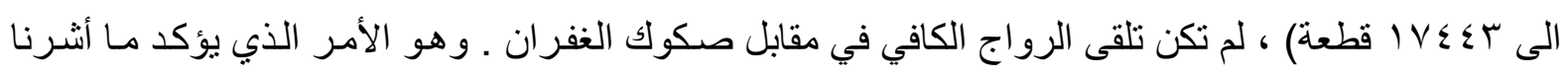

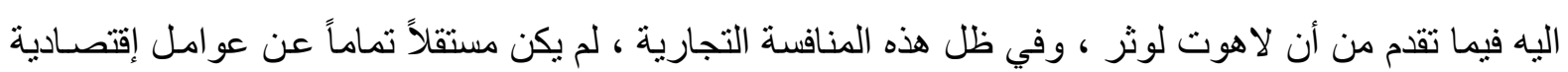

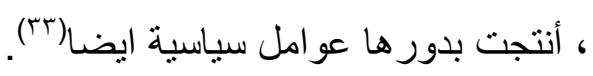

هذه العو امل السياسية ، بادية للعيان من خلال مو اقف الملك فريدريك الداعمة للوثر وحركته الدينية ، بعد نشر الأخير لإحتجاجاته وعلى إثرها ـ بل أن ، من غير المستبعد أن يكون كل نتاج لوثر اللاهوتي في المرحلة

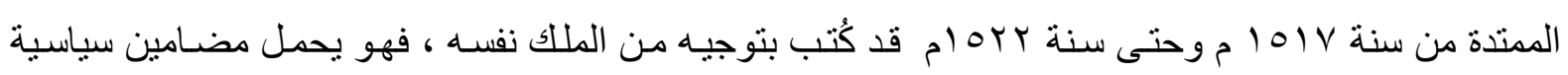
واضحة ، أقل ما يقال عنها إنها مثلت غطاء عقائدياً لثورة سياسية وأجنماعية ، حركها الثـعور القومي الإلمساني تجاه هيمنة الامبر اطورية الرومانية السياسية المعززة بسلطة البابا الروحية .

لقد أخذ الإصلاح الديني بعداً سياسياً معززاً بشعور الالمـان بـانهم مستغلون من قبل البابـا وامبر اطورهم

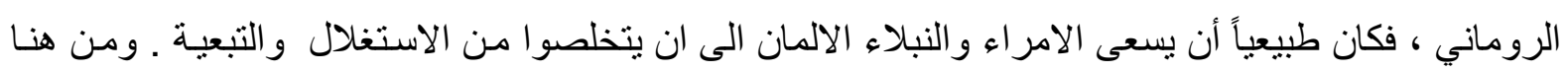

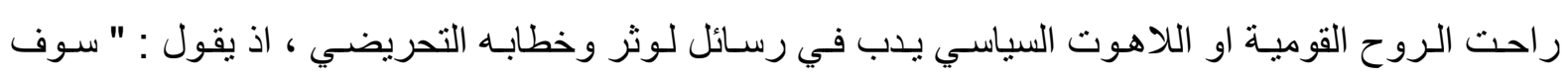

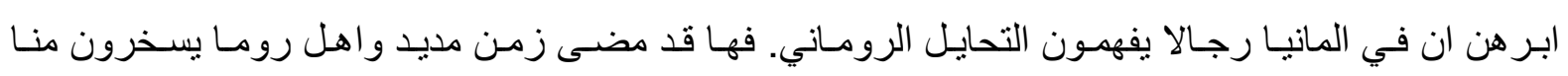

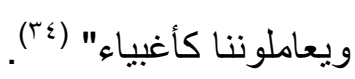

لقـد اسـتجاب ملـك ساكسـونيا لنـداء لـوثر بعـد أن كتـب لـه وبوسـاطة صـديقه وزميـل دراسـته السـابق سبالاتين(Spalatin) وسكرتير البلاط الملكي ، للتنخل في الأمر ـ حيث رفض ان يُحساكم لوثر في محكمة لا

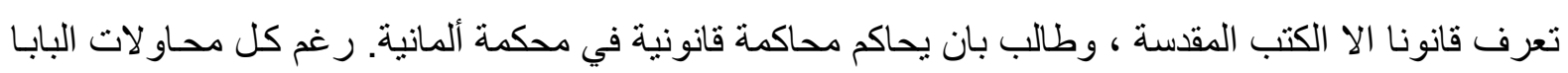
لثنيه عن ذلك بوسائل شتى ( ومنها الو عد بمنحه وردة الذهب، وهو أسمى نيشان تمنحه البابوية ) فيما اذا سلم لـه لوثر لكي يحاكم في روما (ro). وجاء ذلك ، بعد أن أرسل رئيس أساقفة ألمانيا إحتجاجات لوثر إلى روما ونسان ، وبعد

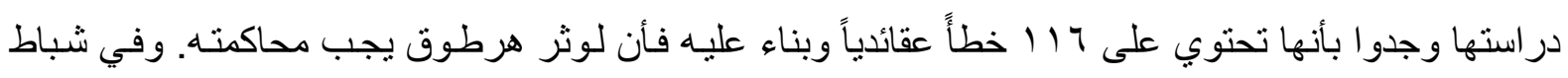
1010 10 كلف البابا ليون رئيس الأساقفة بأن يسحب لوثر احتجاجاته وان يعلن طاعته وخضو عه، و إلا فلابد من ون محاكمته في رومـا ـ وحيّن رفض لوثر ذلك ، أصدرت الأخيرة في تموز أمرهـا إلى لوثر لكي يحضر إلى بلى 
المحاكمة . . وو عد الإمبر اطور الروماني ( العجوز فاكسيمليان) بمطاردته كهرطوقي و إتخاذ الإجر اءات اللازمة لاى السلطات الألمانية لكي تسلمه للمحاكمة في روما. فلم تحصل روما من فريدريك سوى المماطلة . فقي سبيل ثني لوثر عن أراءه ، كان الجدل والجدل المضاد بين لوثر واللاهوتيين الكاثوليك، الذي إستمر أكثر من سنتين، وشهدت عليه أكثر من مدينة ، عاملاً من عوامل تعزيز العقيدة اللوثرية ومضامينها السياسية المبطنة و إنتشار ها أكثر بين الألمان. وقد ظهر ذلك جلياً في تمرد لوثز وأنصاره بحرق مرسوم الحرمان البابوي الصـادر بحقه في تئ حزيران • ror م ـ م وكانت هذه المرحلة هي التي شهدت تحول لوثر من اللاهوت الى اللاهوت السياسي ، تمثل

ذلك بكتابة ثلاثة كتيبات تدعى (كتابات المصلح العظمى) تداخل فيها الديني مع القومي و السياسي ( بَّ). وحتى بعد أن رضـخ امبر اطور رومـا الجديد ( شـارل الخـامس ) لرغبـة ( فريدريك الحكيم ) الى أن تتم

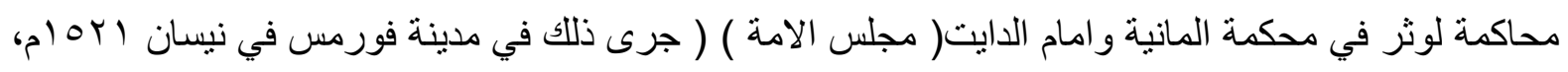
وفي حضـور سياسـي عظيم ممـثلاً بـالامبر اطور نفسـه ، وسـتة مـن الملـوك المنتخبين واربعـة و عشـرين دوق

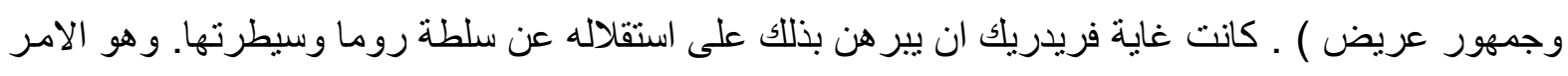
الذي عززه انه منع تتفيذ عقوبة الحكم بهرطقة لوثر ، بعد أن رتب حيلة لاخفائه في قلعـة حصينة حضـي فيها

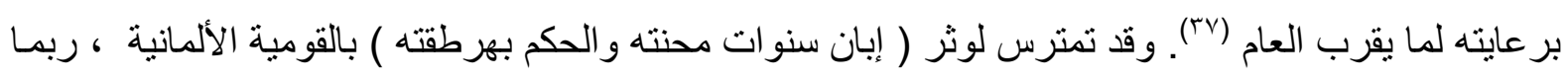
أكثر من المسيح ـ وتحول بشكل مفـاجىه من راهب الى داعيـة سياسـي ! فجـاءت كتاباتهـ في هذه المرحلة

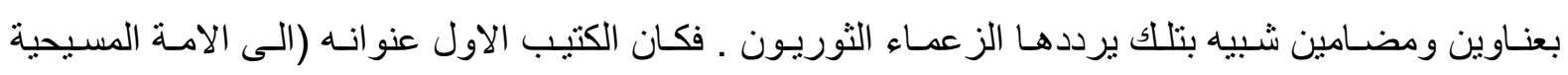
النبيلة) ، و الثاني ( الأسر البابلي للكنيسة ) ، أما الثالث ، فهو بعنوان ( حرية المسيحي ).

إن هذا يبر هن ما نوه عليه المفكر كارل شميدت في كتابـه ( اللاهوت السياسي ) من (( ان ثمـة تمـاثلات عجيـة بين المفـاهيم الحقوقيـة السياسية من جهة و المفـاهيم اللاهوتيـة من جهة اخرى: "القول بحالـة الاستثناء (الطبيعي والسياسي) و الايمان بالمعجزة، ار ادة الثعب وار ادة الله، الامير المدبر والاله المدبر ... ومن جهة ثانية

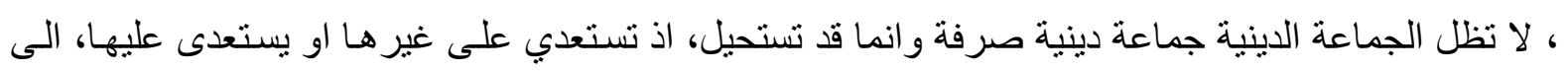

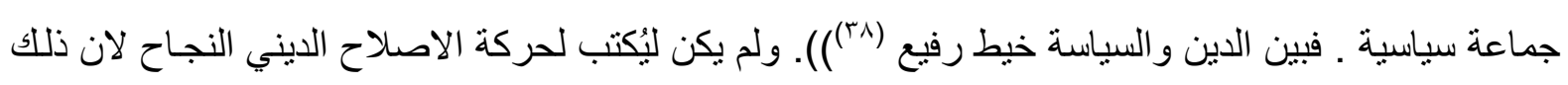

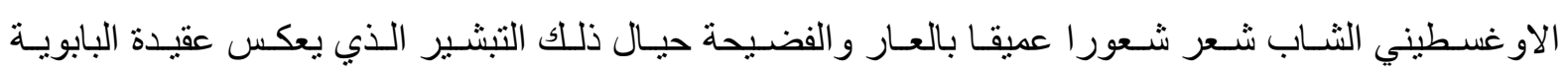
و احبار هـا، ولم يكن لاستهجانه وتنديده بخداع الكنيسـة الكاثوليكيـة. بـل أن مـا جعلها تقف على قدميها ومنحهـا

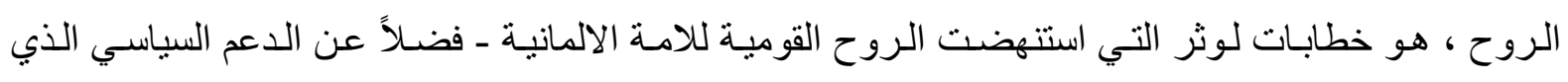

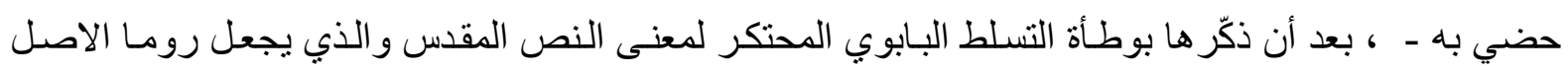

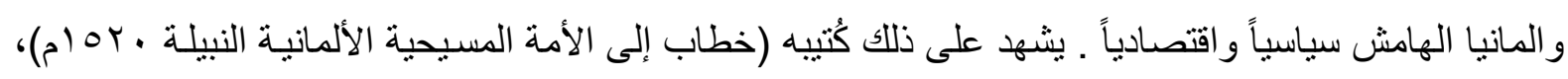
الذي يبئئ بعبارة: (مضى وقت الصمت وجاء وقت الكلام) ـ وكان يريد ان يلفت نظر اصدقاءه وخصومه إلى إلى

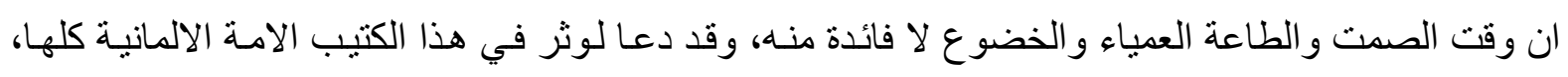
و على راسها الملوك و الامر اء الى القيام بواجباتهم ، ليس تجاه المدينة التي انتخبو الها فحسب ، بـل ايضـا للقيام بواجباتهم الروحية التي تتطلب اصلاحا جذريا عجز الاكليريوس عن القيام له. وقد استعمل لوثر في هذا الكتاب 
لهجة وطنية مناثنداً الثـعب ان ينفض عن كاهلـه التدخل الاجنبـي في شئون الامـة الألمانية، وان يحمل بنفسـة

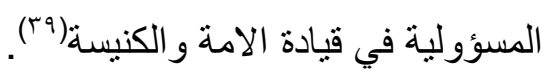

يقول لوثر (( فكيف يكون بأمكاننا نحن الالمان ، تحمل السرقة وذللك النهب لخير اتتا على يد البابـ... فلمـاذا

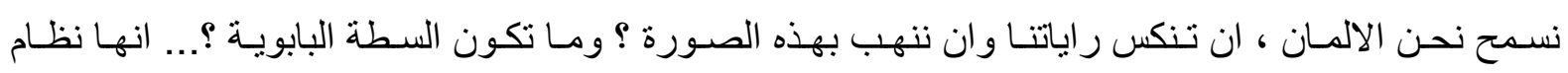
شيطاني ، مشروع صـريح للقرصنة ، واستغفال البشر .. ومـا مادامت تلك السلطة تقود العالم المسيحي الى الدمار جسدياً وروحياً ، فمن واجبنا ان نستنفر كل حماسنا لخوض المعركة على مثنل ذللك الثقاء ومثنل ذلك

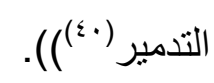

إن المساعي السياسية لهذا الكتاب ، جاءت لإجل هدم اسس إحتفاظ رومـا بالسلطة في المانيا ، وبو اسطة زعزعة السلطان الروحي الذي تعتبره الكنيسة فوق السلطان الزمني ـ أي خضوع الابـاطرة و الملوك والامر اء للسلطة الروحية العليا الا و هي سلطان البابا وسلطة الكنيسة - ـ فلا يوجد ( بحسب المسيحية الجديدة اللوثرية ) امام الله اكليريوس ، فان مجيء المسيح غير اوضـاع كاهن العهد القديم لأن المسيح هو كاهن العهد الجديد ، و هو الكاهن و الذبيحة في نفس الوقت. كما ان لوثر دعى ايضا جميع المؤمنين المسيحيين ان يكونو اكهنـة مثله، فليس الكاهن المرّسم وحده الكاهن الحقيقي بل ان الكاهن الحقيقي هو الذي يقبل المسيح بسوع مخلصـاً وفادياً.

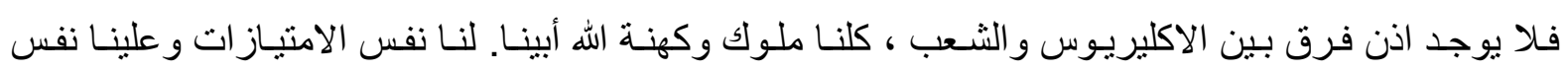
الواجبات. و على كل مؤمن ان يقوم بالعمل الموكل اليهل فالخـادم يعمل كخـادم و المدبر يعمل كمدبر و الحـاكم كحاكم. هذا هو الحاجز الكبير الذي فرضنه الكنيسة على الشعوب وحاول لوثر هدمـه(1) ـ وهو بذللك أر اد إنهاء

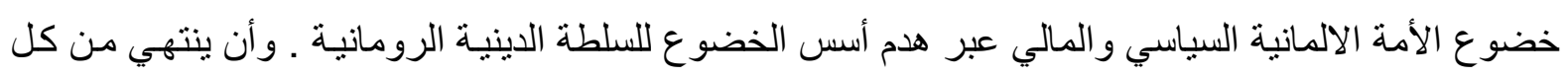

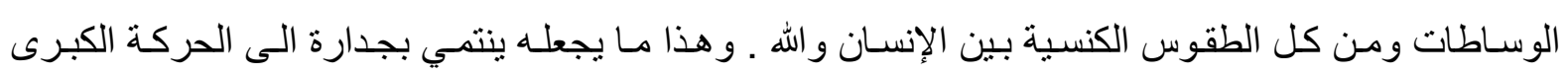
الساعية للعلمنة ، على حد وصف الفيلسوف الفرنسي ألان تورين(r)؛. و على الرغم من أن لوثر لـ يكن نتاجـاً

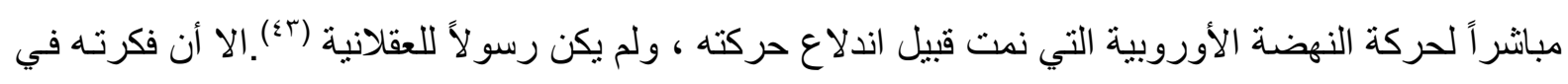

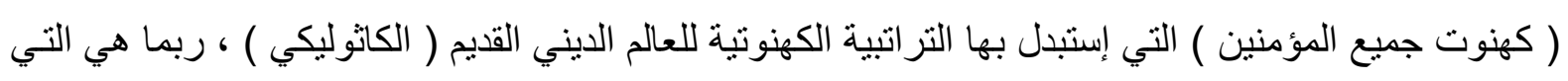
دفعت دوركهايم أن يعّد البروتنتانتية مصدراً لعبادة الفرد الحديثة . كما يشير الى ذلك عالم الأجتمـاع البريطاني

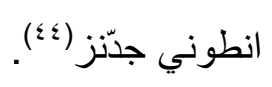

" قضي الأمر ـ انقلبت العلاقة بين الإنسان و الله الى غير رجعة ـ ضربت حركة لوثر مبدأ الوسـاطة في

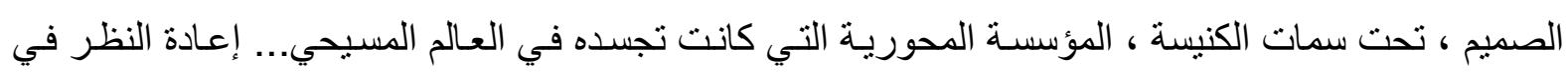
مسألة الوحدة بين السماء والأرض التي أثثيرت ، نشكل الخطوة الأولى بأتجاه العصر الحديث...أن فلك الارتبـاط بين المرئي و غير المرئي الذي يعلنه لوثر يتضمن مدى أبعد من إعادة تعريف الإيمان المسيحي ـ إنـه يُدخل في

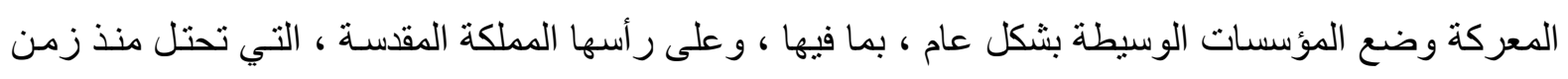

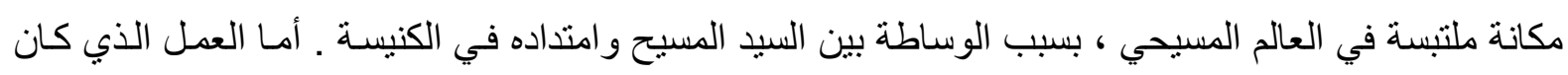

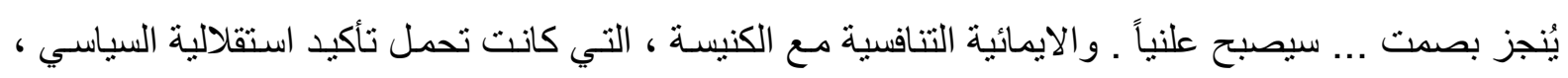


وتحجبه في آن ، ستطرح ثمار هـا... إثـارة ثورة السياسي على الديني التي ستزدهر وتتألق بعيداً عن المدن

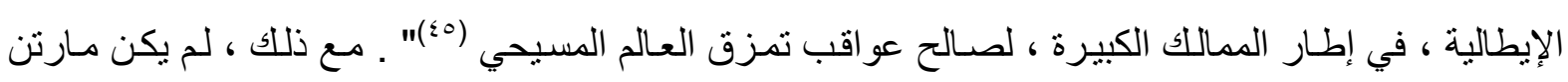

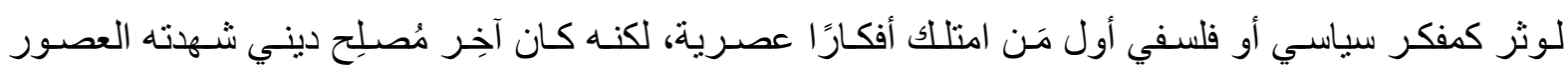

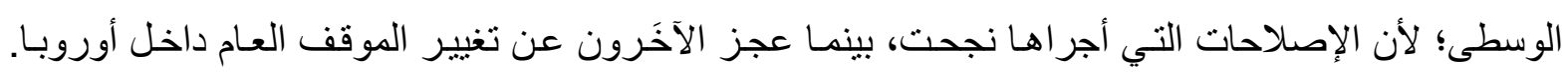

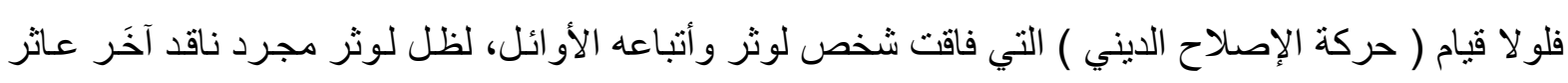
الحظ للكنيسة الرومانية في العصور الوسطى، وربمـا كان سيُعدَم شـأن غيره من المصلحين المخلصين الذين

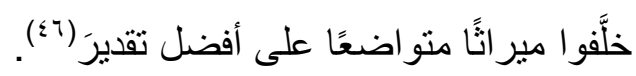

وكما يُصور نصب مدينة فورمس التذكاري ( الاصلاحيون الأربعة الكبار أسلاف لوثر ) ، يُنشير أيضـا ،

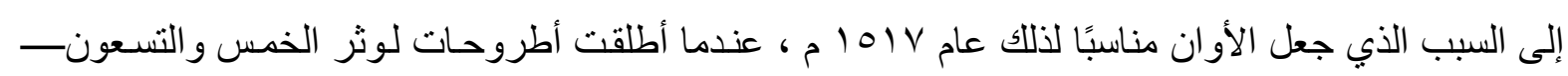

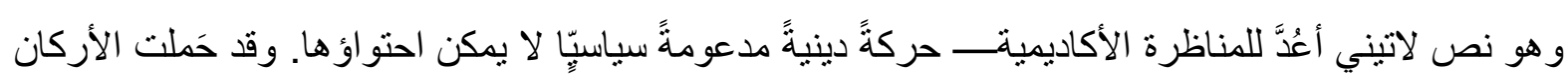

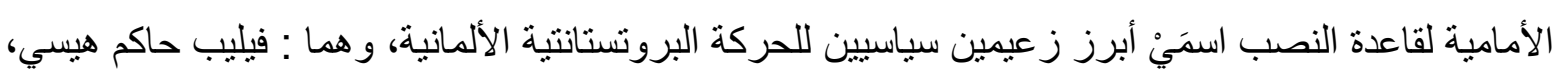

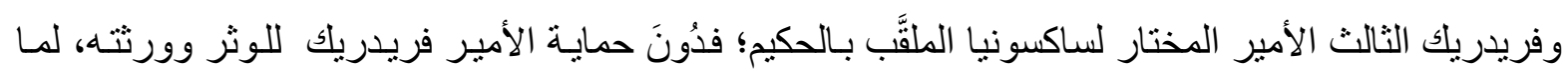
أمكن للوثر أن يُفلت من المرسوم الذي صدر ضده وضد أتباعه في فورمس، ودُونَ النفوذ العسكري و السياسي

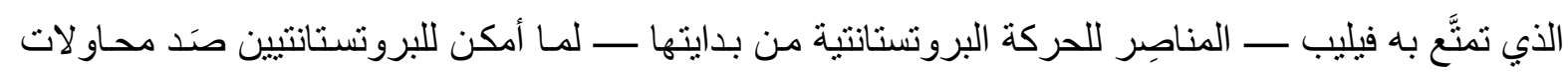
الإمبر اطور شارل الخامس لعرقلة حركة الإصلاح الديني.

\section{المبمث الرابع : مآلات اللاهوت السياسي وانتكاس الاصلاح الدينبي}

كان لوثر متخفياً ( بر عاية ملكية ) في قلعة فارتنبرغ بعد محاكمته في نيسان البه ام ، وييدو أنه قد عاد

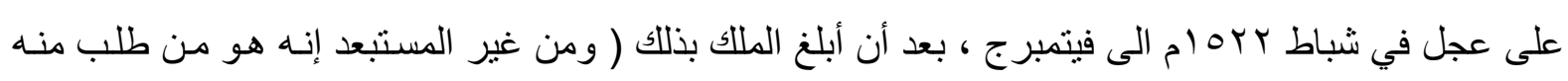

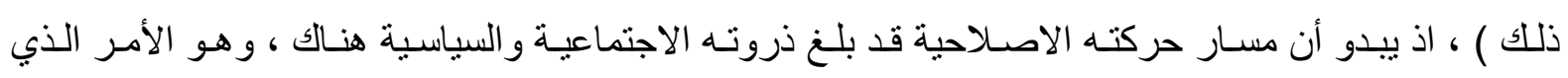

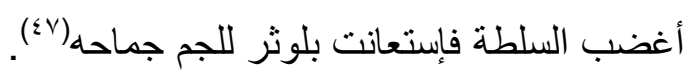

ما حدث هو أن ظهر عدد كبير من القادة والمعلمين الوعاظ والمبشرين مثل صديق لوثر ( كارلستادت (Carlstadt الذي كان يعتبر نفسه الرئيس الروحي لفيتمبرج بغياب لوثر، ومطبق تعاليمهـ ـ وقد ذهب بعيداً في عملية التغير الجذري. فقد فكر في إلغـاء الأديرة وحل فعلاً جمعية الرهبان الاغسطينية في فيتمبرج في كانون الثاني بro 10، وشجع الرهبان على الزواج. كما وزع ممتلكات الأديرة لمساعدة الكنائس واستخدامها في المشاريع العامة. كما انه ألغى بعض التقاليد الكاثوليكية السائدة مثل الصور و التماثيل و الملابس الكهنوتيـة. وفي لتي

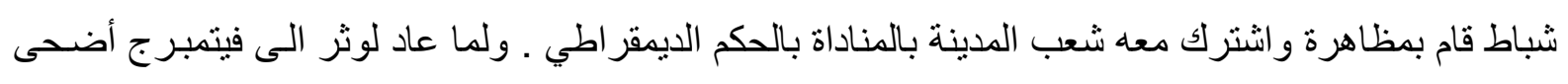
صديقه القديم خصمه ، و احتج عليه في عظاته ــ و هو مـا أسـهم في نفى كارلستادت من ساكسونيا بتهمة إثارة الاضطر ابات. فالاخير كان يريد الحلول الجذرية والسريعة ، أما لوثر فكان يتحجج بأن التغيير يجب وفي أن يكون

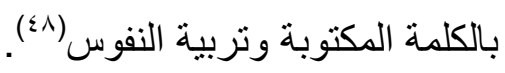


إن اللوثريين المتحمسين أر ادو أن بطبقوا واقعياً مبادى لوثر التي أوحت بها نصوصسه اللاهوتية ، فأعادوا

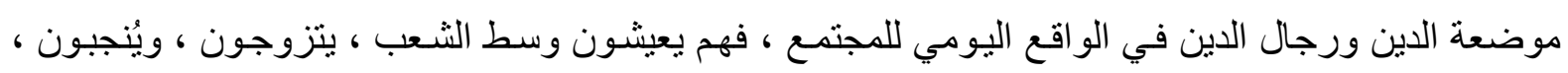

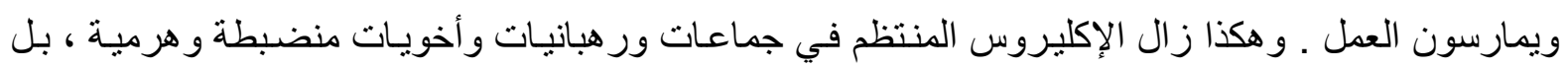
كنائس تدير ذاتها بذاتها ـ. وقد أُجيزت وقُبلت من قبل السلطة المحلية ، شريطة أن تستمر في تكريس رفضـها القاطع لأتباع كنيسة روما والحبر الأعظم ، وأيضـاً شريطة ألا تمس بسوء النظام المتمعي القائم وهرمياته ،

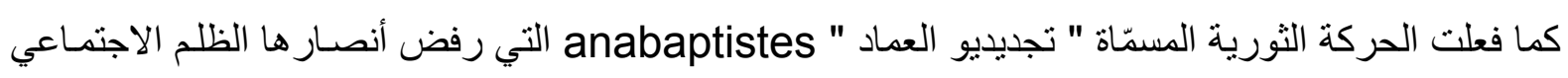

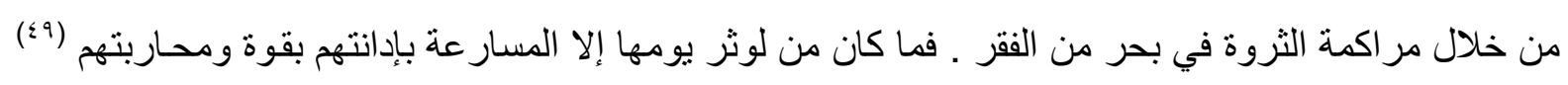
ـ ويبدو أن نز عة لوثر المحافظة هذه ، كانت في حقيقتها اداة للسلطة في وئد تطلعات الثعب الألماني ( و التي

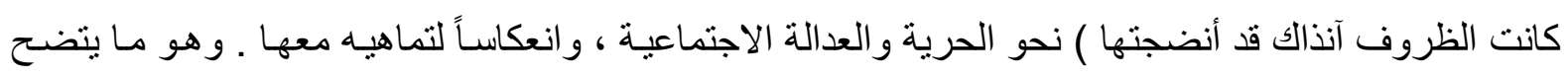

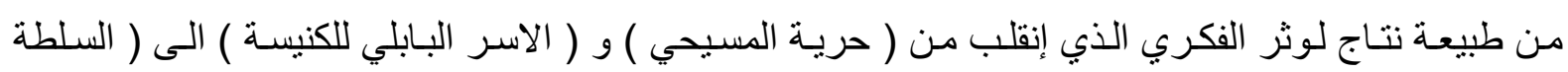

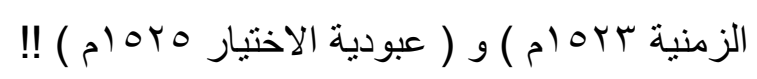

وما أكد أكثر الوجه "المفسد" للوثر "المصلح" . هو موقفه البغيض تجـاه أبنـاء شعبه من الذين استلهموا

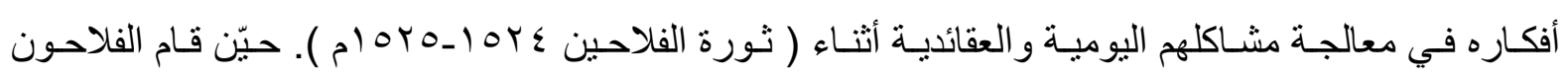
بحركة ثوريـة أخذت بالاتسـاع بعد أن انظم اليها العمال. فأجتمع ثناثين ألف رجل لا يعترفون بأي قانون الا

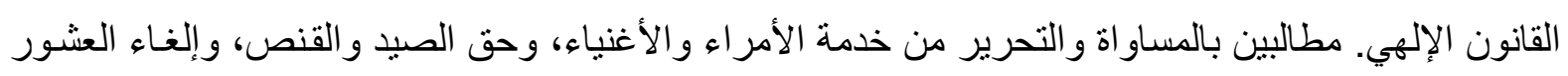
التي كانت تدفع للكنيسة وللامر اء ـ و اقتحموا القصور و الحصون(.0) ـ فما كان موقف لوثر من ذللك ؟ ان كثيرين من الذين قاموا بتحليل هذه الحوادث دهشوا من موقف لوثر إزاء الفلاحين عندما قـال للأمراء

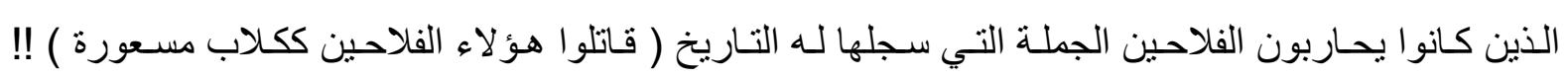
وستظل الجملة بلا جدال نقطة سوداء في تاريخ هذا الرجل ــ وان قولاً كهذا يعد عثرة ليس فقط لإنسـان القرن العشرين بل حتى لإنسان القرن السادس عشر (1). ان ملهم التغيير قد خذل الفلاحين ، فليس على هؤلاء الا التزام الصدت والطاعـة .لان الامر بيد السلطة الزمنية والنبلاء ـ فالخلاص لا يتحقق الا بيد هو لاء. ـو أخذ يلوم اتباعه لانهم لم يفهموا دعوته. فلاحين وحرفيين

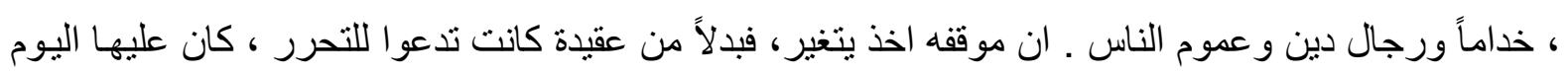

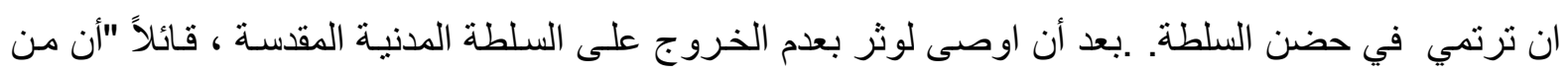
يعارضون النظام القائم بمباركة الله يجلبون على انفسهم الادانة (roان)".

لقد ردَّ لوثر على مطالب الفلاحين في منشور سُمِّي (نصح من أجل السـلام ) إذ ظل مثنار خوفه الأكبر هو احتمال اندلاع ثورة تتمخض عن فوضى أو ـ على حد تعبيره - "دمار ألمانيا إلى الأبد بالإطاحة بكلمة لله

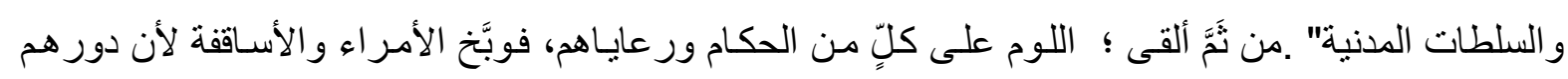

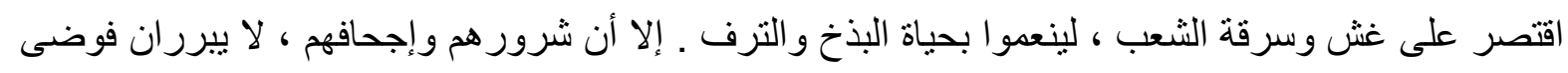

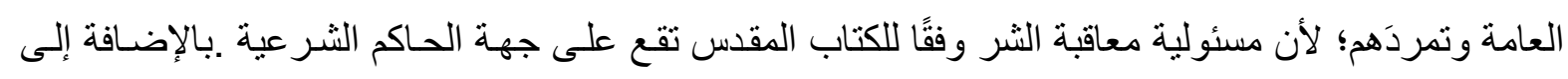


ذللك، إن كان الفلاحون مسيحيين مخلصين كما يزعمون ، فعليهم أن يُذعنو الوصية المسيح بـأن يديروا الخد

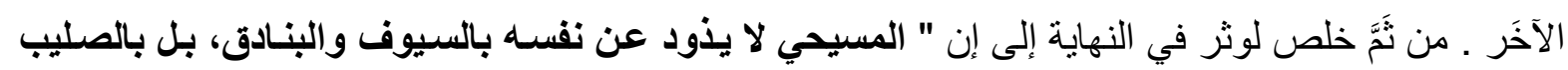

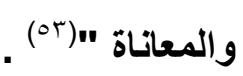

لقد حمى الامير ( فردريك الحكيم) لوثر، بـل ان الاصـلاح اللوثري لم يكتب له النجاح بدون سلطة هذا

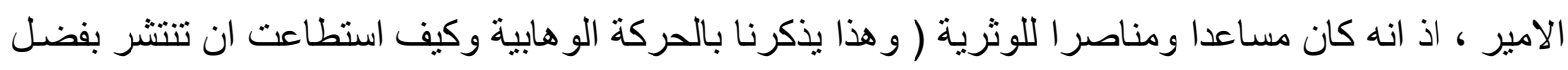
سلطة احد امر اء نجد وكيف اصبحت حركة "اصـلاحية" تنشـ الدين "الحق" وتكفر الاخر، اليهود و المسيح والثيعة وكل ما لا يتفق مع رؤيتها السلفية المتطرفة ) ، فكان لوثر بار اً بولي نعمته ، بأن أكد أن السلطة المدنية

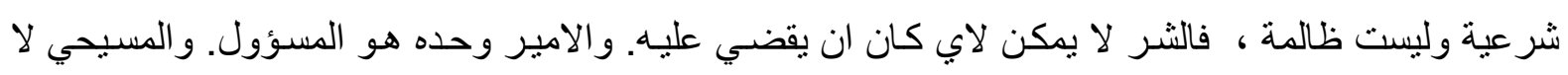

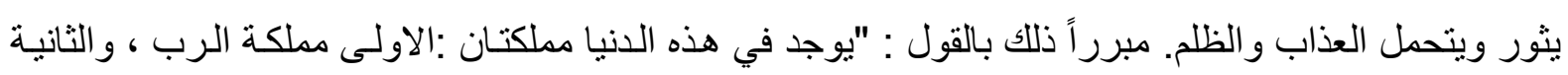

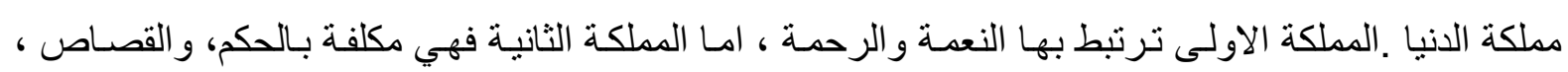

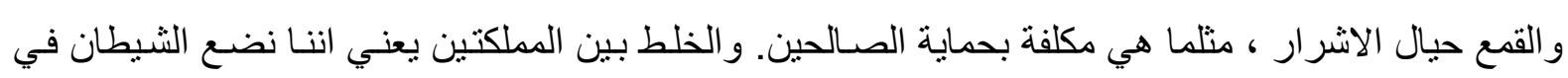

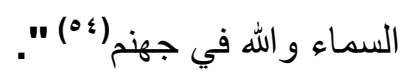

ان هذا يُدلل بما لا يقبل الثنك ، إن لوثر لم يكن "رجل ثورات" ، إذ انه لم يحساول القيام بحرب أو مقاومـة للسلطات القائمة في عصره ـ ومع ان لوثر قد ثار ضد التعاليم المدرسية الا انه ظل متمسكا بكثير من تعاليم القرون الوسطى. و هو ما ظهر جلياً في كتابه ( السلطة الزمنية ) الذي كان حجر الزاوية لنظريته عن الدولة.

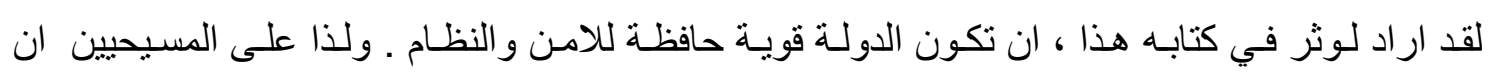
يتصفوا بأخلاق الطاعة والامتثال لكي تتحقق السلطة العادلة عبر جهاز الدولة . فالمسيحي برأيه يجب عليه ان

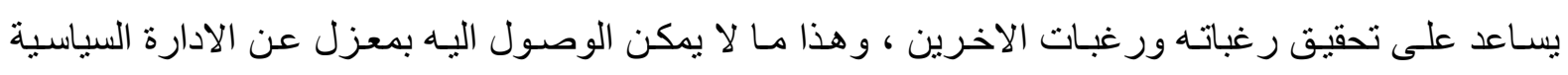

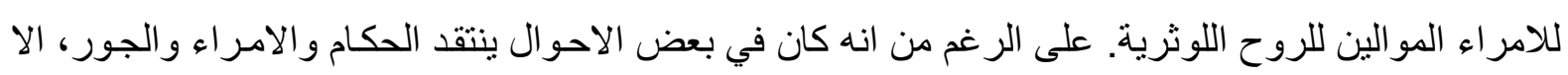

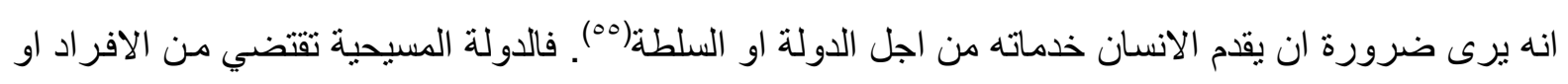

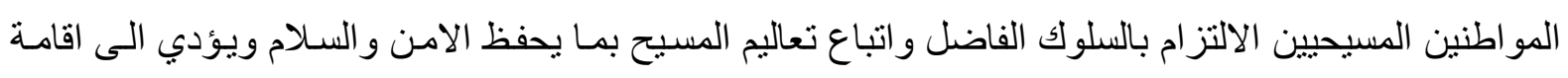
نظام مسيحي عادل يقضي على كل ما يسير في درب الضلال و الفسـاد ويعمر كلمـة الرب عبر الدولة المعززة

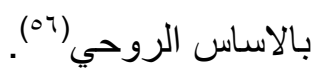
ومما يثير السخرية ان لوثر " ذللك الذي دفع في اتجاه الحرية الفكرية في العالم الروحاني ، نر اه في العالم

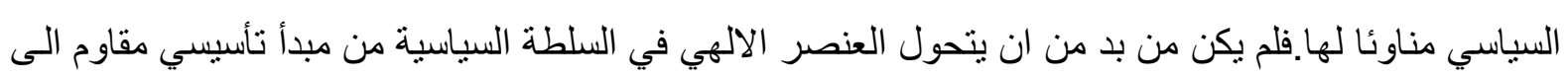

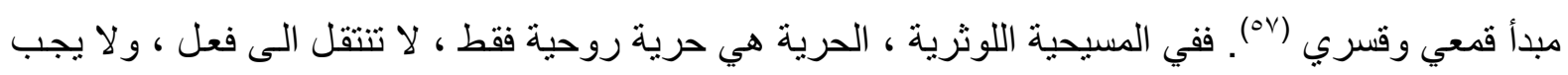

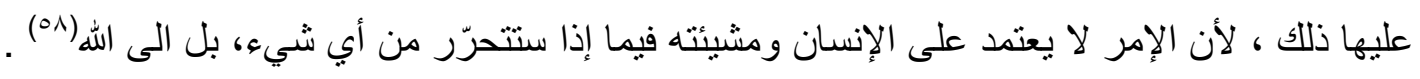
لقد عزز لـوثر البنيـة النفسية الاجتماعيـة للتسـلط السياسـي ، بعد أن الغـى حريـة الإر ادة في منظومتهـ

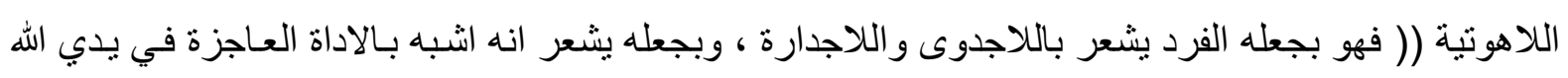

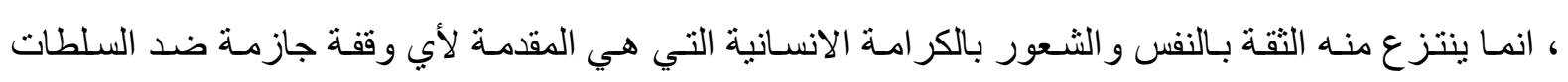


الدنيوية القاهرة (90)). و أن لمن المؤكد إن فيورباخ كان محقاً في نقده السـاخر للوثر ، بعد أن قابل الأخير بين

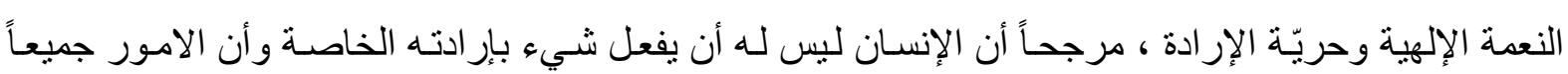
مردها للنعمة الإلهية ـ يقول فيورباخ (( في الدين تُعتبر طبيعة الإنسـان منفصلة عن الإنسـان ـ الفعالية ، النعمـة

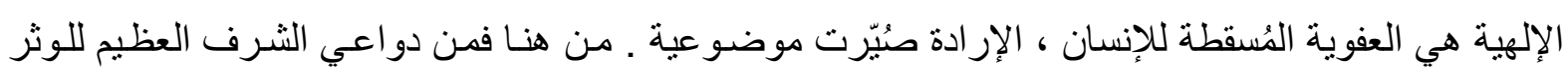

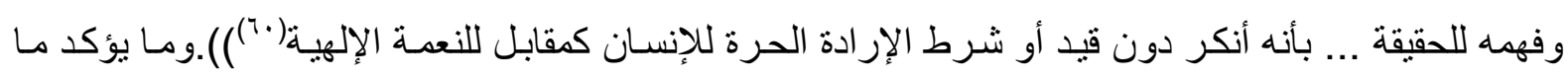

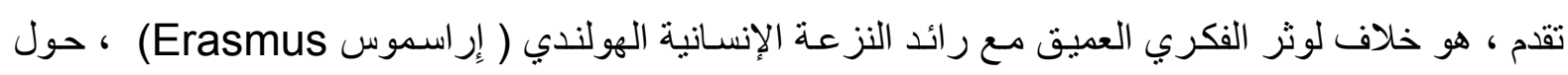
رؤية الأخير في كتابه (رسالة في حرية الأختيار) ، التي رد عليها لوثر في رسـالته ( في الجبر ) ـ لقد نـاهض الإن لوثر أصحاب هذه التوجهات الذين عملوا على التوفيق بين روح عصر النهضة والإصلاح ، والإيمسان والمعرفة

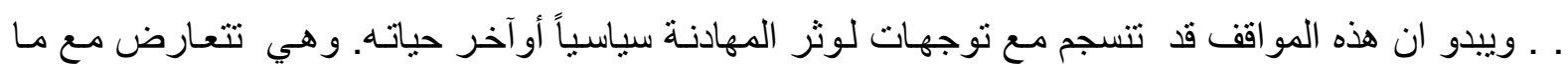

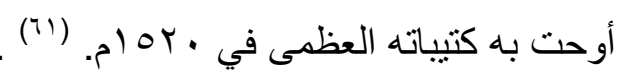

لقد راحت الكنيسـة تخضـع لسلطة الامير السياسية ، بعد مـا كانت منفصلة عن سلطة الدولـة ونظامها وقو انينها "كانت الكنيسة في القرون الوسطى مستقلة عن الدولة ، فكان لها تنظيمها وقانونها الكنسي ونظامها المالي ، الخاص بها ـوكانت مترفعـة عن الفروق القوميـة والسلطات الزمنية المتغيرة ـولكن الكنيسة اللوثريـة انطبعت (خلافـا لذلك) بطابع الاقليميـة والمذهبيـة وانصـاعت لوصـاية الدولة التي اخذت تنظم الثـعائر الدينية

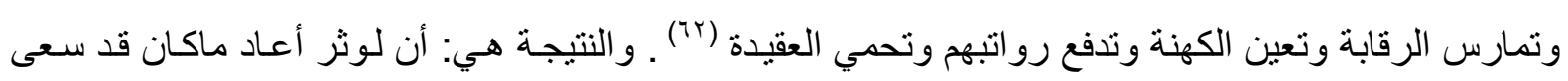

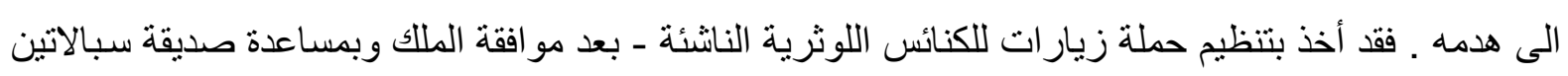
(Spalatin) وأصول الإيمان المختصر). ليرّسخ بنـاءه الكنسي الجديد في ( الوصسايا العشر وهي عبـارة عن مر آة للخطية،

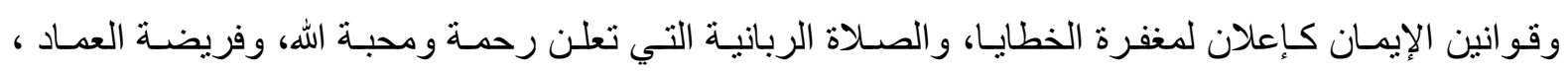

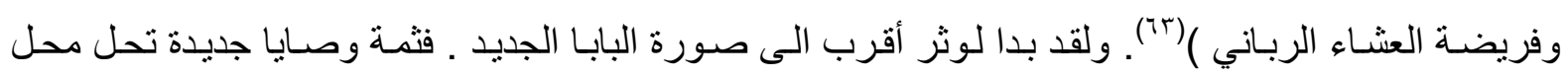

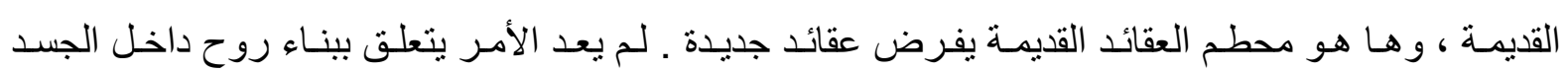
المتداعي للكنيسة القديمة ، بل وجود كنبسة اخرى مقابل كنيسة، كنيسة منقطعة كليا عن الاخرى ، بكيان أميري زمني متحجر ، مهيمن وذي مصالح ومنافع . فغدا مُجدد الدين سلفياً وأنتكس الإصلاح على يديه في النهاية.

\section{الخاتمة}

لم يختلف حُكم التاريخ على رجل، بقدر إختلافه على لوثر. فهو تـارة ، الر اهب المضطرب قلق الروح

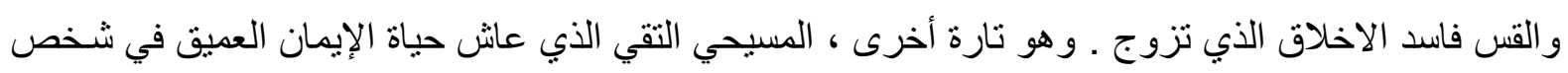

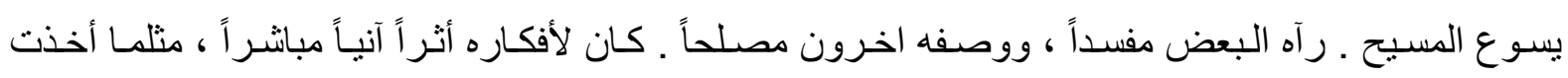

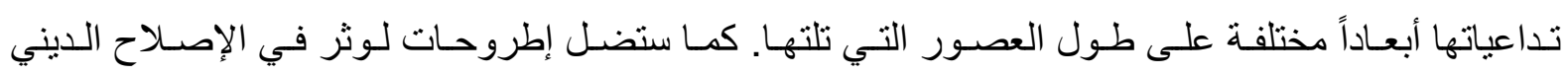
موضـوعاً خصباً للنقاش و إختلاف الرؤى. فمن ناحيـة، كانت عقيدته في البر بالإيمـان ولا جدوى الأعمـال ،

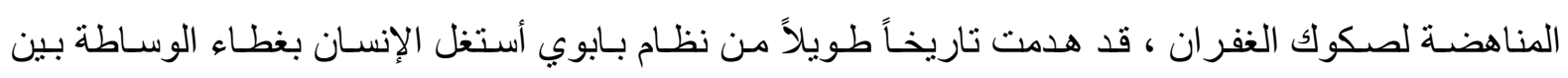


الارض والسماء ، بين الإنسان والله. وممثلوا الله المحتكرون لاسر ار الكتاب المقدس قد فقدوا سطوتهم بعد أن فكلك لوثر طلاسم هذا الكتاب العبرية وجعله في متناول الجميع حيّن أنجز أعظم أعماله بترجمته بعهديـه القديم و الجديد الـى اللغـة الألمانيـة ـ وليس من عصـمة الا للإنجيـل المقدس الذي يمكن للمسيحي المستنير أن يُشَّر بكلمته، وهو ليس بحاجة لقساوسة لهدايته. لذا ، ومن هذه الناحيـة فأن لوثر غدا داعية النزعة الفرديـة ومبشر

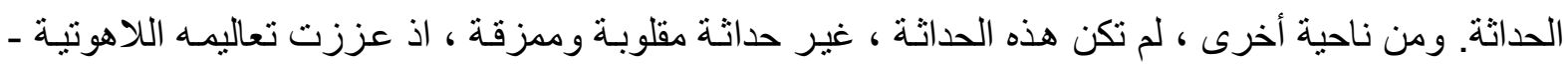
في الجبرية ونفي الإرادة الإنسانية في مقابل الإرادة الإلهية ـ شعور الإنسان بالعجز ، مما اسهم في توفير بنية

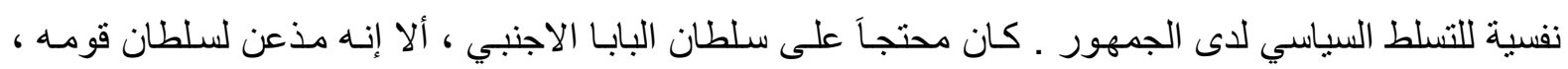

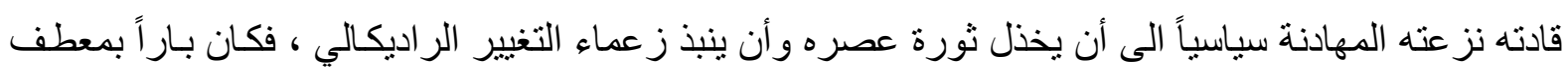
السياسة الذي لو لاه لم يخرج إصلاحه الى النور ولم يُكتب له النجاح .

كـان لـوثر رجـلاً واحداً ، ولكن بوجـوه شـتى ـ وهـو لـوثر ذو الرؤوس السبع ـ كمـا وصـفه أول كاتب كاثوليكي لسيرته .

\section{هوامش البمث}

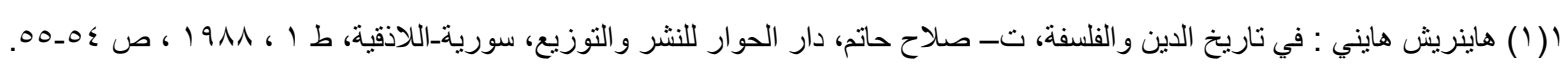

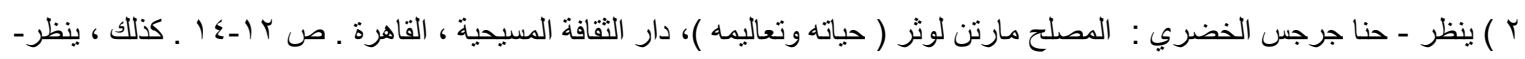

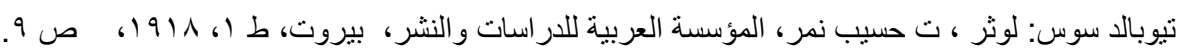

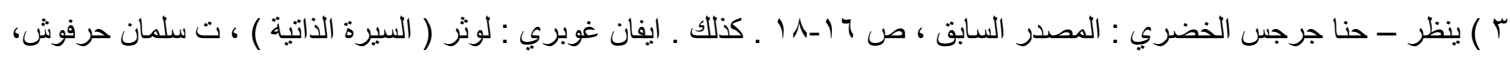

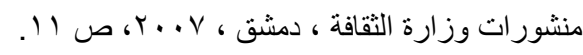

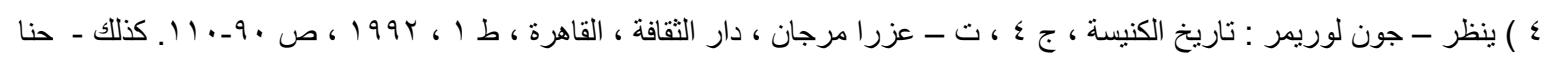

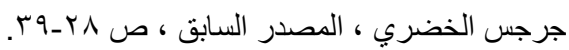

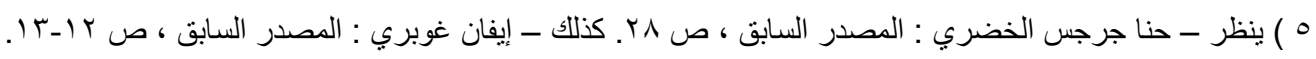

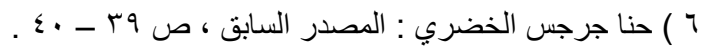

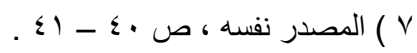

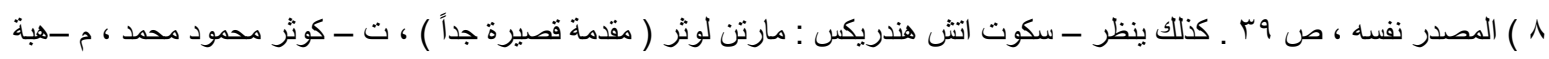

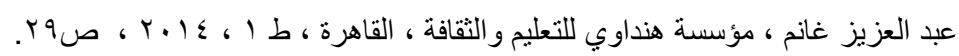

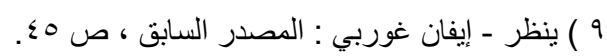

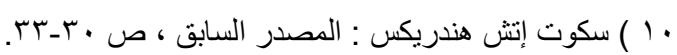

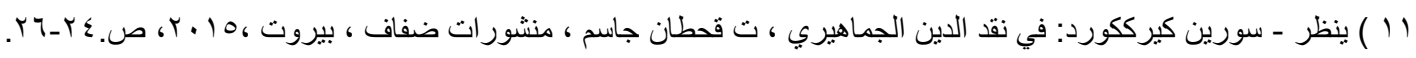

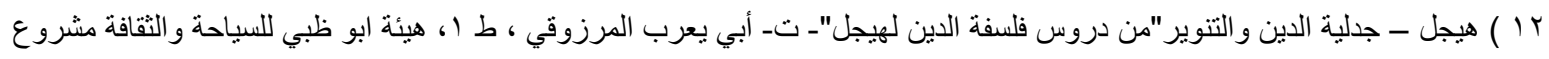

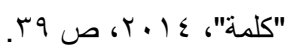

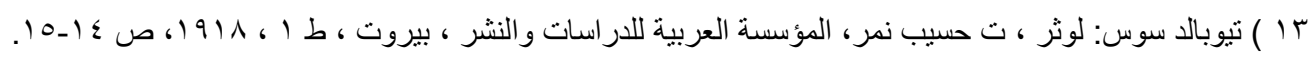

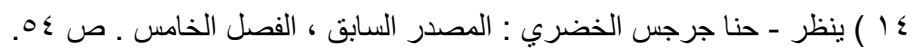

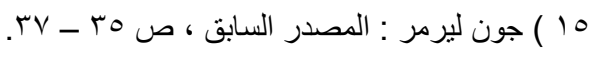

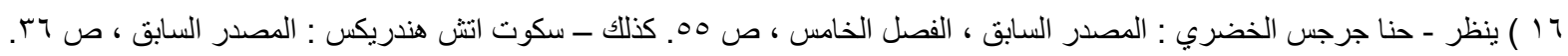

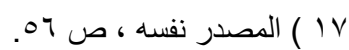

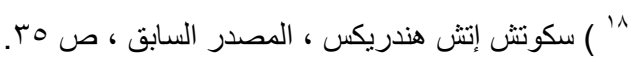

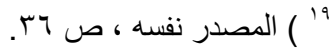




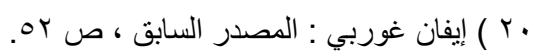

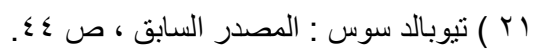

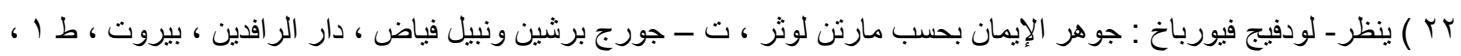

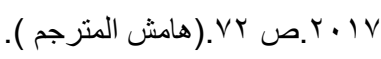

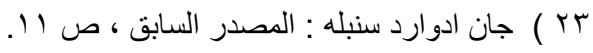

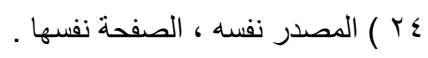

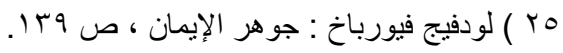

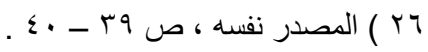

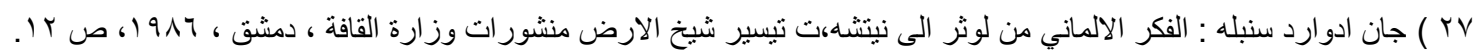

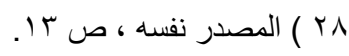

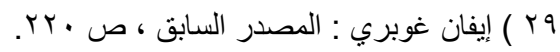

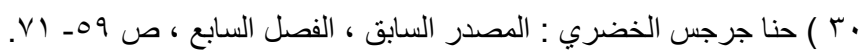

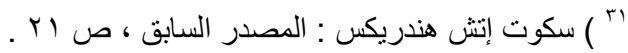

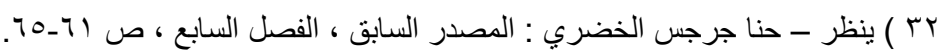

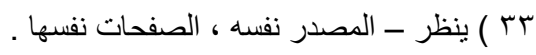

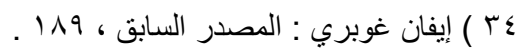

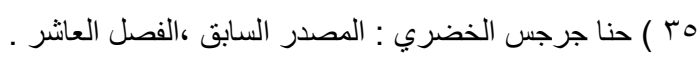

צr ) ينظر - المصدر نفسه ، الفصل العاثر.

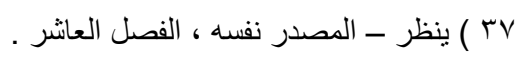

^ץ ) محمد الثيخ : فصل المقال فيما بين السياسة و اللاهوت من اتصال عند كارل شميت، ضمن كتاب الدين والسياسة من منظور فلسفي

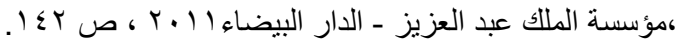

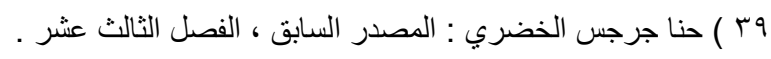

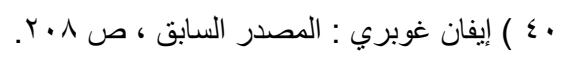

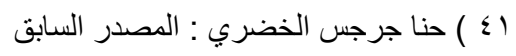

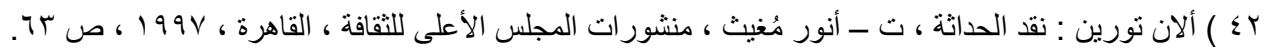

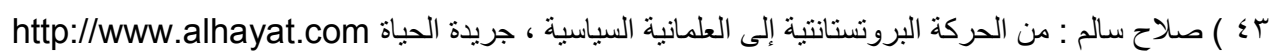
§ ؛ ) انطوني جدّنز: الر أسمالية والنظرية الإجتماعية الحديثة ( تحليل كتابات ماركس ودركهايم وماكس فيير ) ، ت ـ أديب شيش ، الهيئة العامة

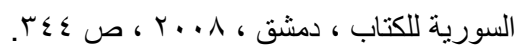

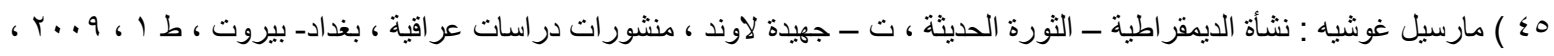

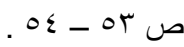

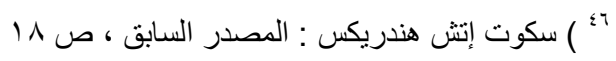

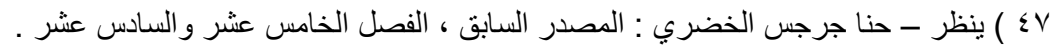

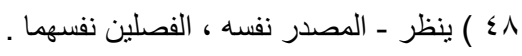

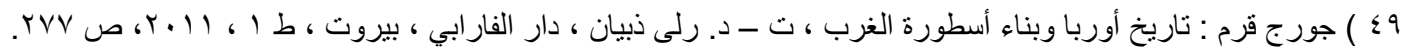

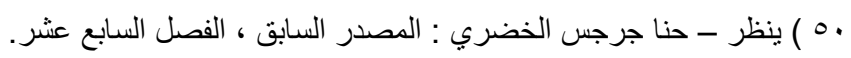

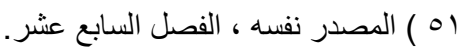

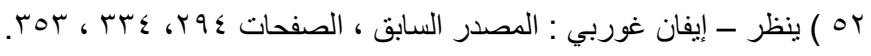

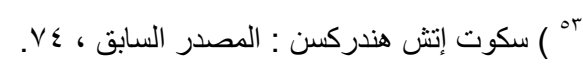

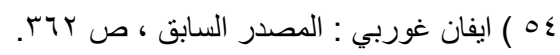


هه ) ستيفن ديلو تيموثي ديل : التفكير السياسي والنظرية السياسية والمجتمع المدني ، ت - ربيع وهبة ، منشور ات المجلس الأعلى للثقافة ،

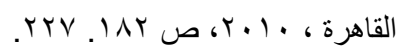

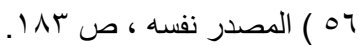

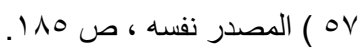

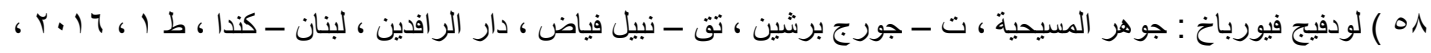

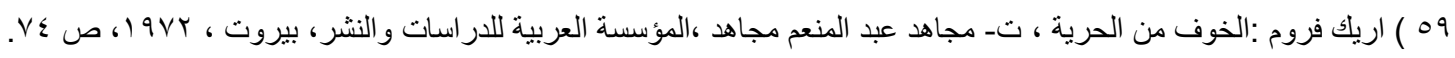

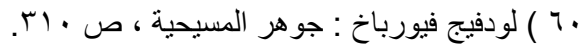

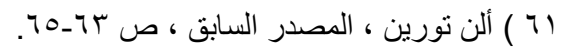

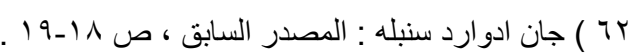
rا ) ينظر - حنا جرجس الخضري : المصدر السابق ، الفصل التاسع عشر.

\section{قاتمبهة الإمادر}

ا - انطوني جدّنز: الر أسمالية والنظرية الإجتماعية الحديثة ( تحليل كتابات ماركس ودركهايم وماكس فيير ) ، ت ـ أديب شيش ، الهيئة

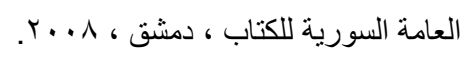

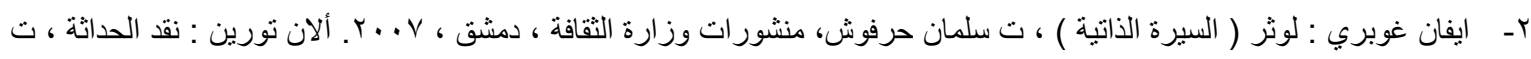

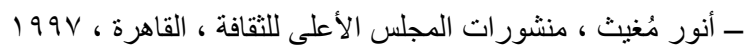

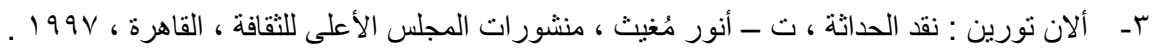

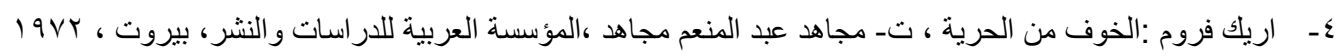

هـ حنا جرجس الخضري : المصلح مارتن لوثر ( حياته وتعاليمه )، دار الثقافة المسيحية ، القاهرة ـ ب ت. ت.

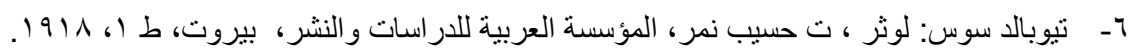

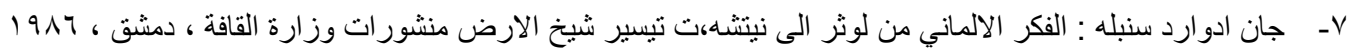

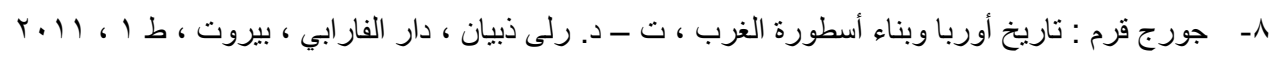

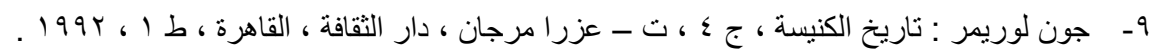

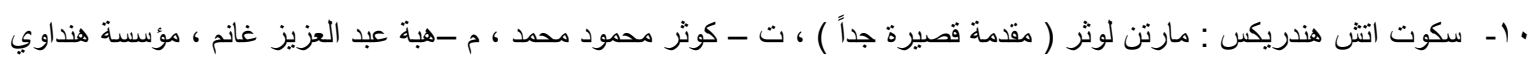

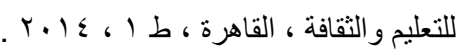

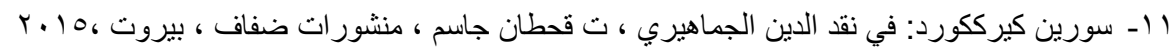

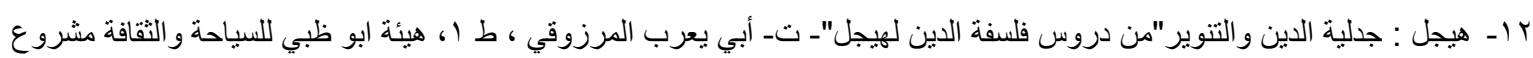

"كلمة"،

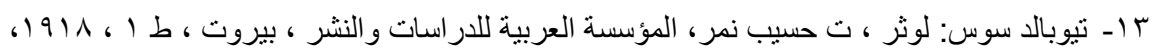

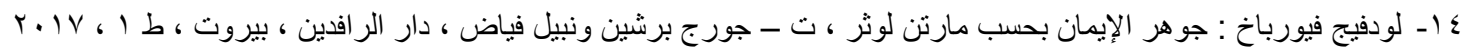

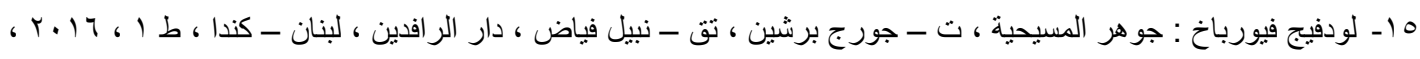

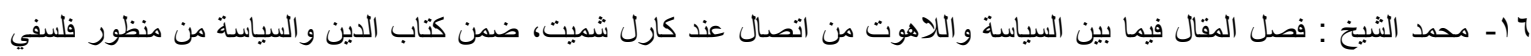

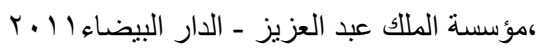

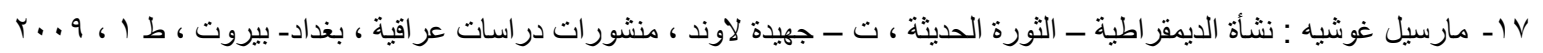

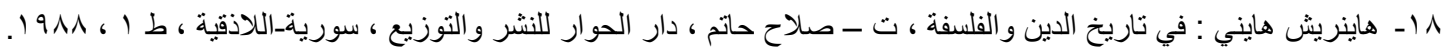

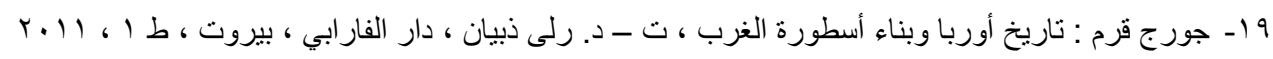

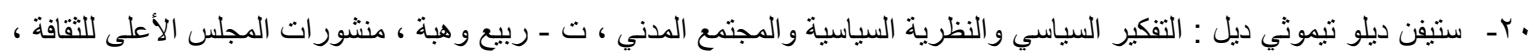

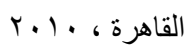

